\title{
Multiple Sclerosis in relation to sex steroid exposure
}

\author{
Per Kempe
}

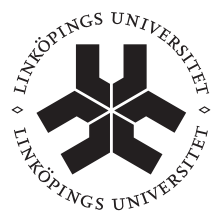

\section{Linköping University} FACULTY OF HEALTH SCIENCES

Division of Obstetrics and Gynaecology Department of Clinical and Experimental Medicine Faculty of Health Sciences, Linköping University

58185 Linköping, Sweden Linköping 2014 
(C) 2014 Per Kempe

ISBN: 978-91-7519-257-4

ISSN: 0345-0082

Published articles have been reprinted with permission from the publishers.

Paper I (C) Informa Healthcare

Paper III C Elsevier

Printed by LiU-Tryck, Linköping, Sweden, 2014 
To Sara, you are the sunshine of my life.

"You know, my faith is one that admits some doubt" Barack Obama 


\section{SUPERVISOR}

Jan Brynhildsen, Associate Professor

Division of Obstetrics and Gynaecology, Department of Clinical and Experimental Medicine, Faculty of Health Sciences, Linköping University, Linköping, Sweden

\section{CO-SUPERVISOR}

Mats Hammar, Professor

Division of Obstetrics and Gynaecology, Department of Clinical and Experimental Medicine, Faculty of Health Sciences, Linköping University, Linköping, Sweden

\section{OPPONENT}

Matts Olovsson, Professor

Department of Women's and Children's Health, Uppsala University, Uppsala, Sweden

\section{EXMINATION BOARD}

Tommy Sundqvist, Professor

Division of Medical Microbiology, Department of Clinical and Experimental Medicine, Faculty of Health Sciences, Linköping University, Linköping, Sweden

Tord Naessén, Professor

Department of Women's and Children's Health, Uppsala University, Uppsala, Sweden

Magnus Vrethem, Associate Professor

Division of Neurology, Department of Clinical and Experimental Medicine, Faculty of Health Sciences, Linköping University, Linköping, Sweden 


\section{ABSTRACT}

Multiple sclerosis (MS) is a potentially severe chronic inflammatory disease of the central nervous system (CNS) and is usually diagnosed between 20 and 40 years of age. The incidence of MS is two to three times higher among women and the type and course of the disease often differ between the sexes. Sex steroids, especially estrogens, have been shown to influence the immunopathology involved in MS and the mouse model experimental allergic encephalomyelitis (EAE), as well as radiological and clinical signs of the disease. The ovarian cycle and hormonal contraception result in fluctuations in sex steroid concentrations that could possibly affect MS. The incidence of MS in women is highest at an age when a reliable contraceptive method is an important matter but the effects of estrogen-containing combined hormonal contraceptives (CHC) on MS have not been thoroughly studied. The general aim of the research for this thesis was to investigate how fluctuations in sex steroid exposure during the menstrual cycle and use of $\mathrm{CHC}$ affect MS in a clinical context.

Paper I is based on female MS patients with or without hormonal contraception. Symptoms were reported prospectively in an MS-symptom diary. In contrast with results from previous retrospective studies, 16 women without hormonal contraception reported fewer complaints regarding one out of 13 symptoms during the low estrogen/progesterone phase of the menstrual cycle. Seven women who used CHC experienced three of the symptoms significantly more strongly during the low estrogen/progestogen, pill-free period. In paper II 22 women with MS who used CHC reported higher scores for four out of 10 symptoms during the "pill-free" week, i.e. during the low-estrogen/progestogen phase using a modified symptom diary. Women with MS who did not use hormonal contraception reported no differences in symptom scores between high and low estrogen/progesterone phases. Paper III included 770 women who answered a questionnaire that was designed to investigate whether longer periods of high estrogen concentration such as CHC-use and pregnancies delay the onset of MS. The mean age at MS onset was significantly higher among women who had been using COC before their first MS symptom (26 vs 19 years, $p<0.001$ ) and the longer the women had been using $\mathrm{COC}$ the higher the mean age at MS onset. The number of children born before the first symptom of MS was positively correlated with age at MS onset $(r=0.6 ; p<0.001)$. Paper IV aimed to investigate if peripheral blood levels of cytokines, chemokines, and transcription factors for different Thelper (Th) cell subsets change in relation to high and low estrogen/progestogen states in women with MS and healthy controls with and without $\mathrm{CHC}$ using multiplex bead technology and qPCR. Expression of the B cell-associated chemokine CXCL13 was generally higher in high the estrogen/progestogen phase than in the low estrogen/progestogen phase and the expression of the transcription factors showed a general activation of peripheral blood T cells during high estrogen and progestogen phases in women with MS as well as in healthy women.

The clinical implication of these and other studies is that there is probably no reason for avoiding $\mathrm{CHC}$ as a contraceptive method in women with MS. It is also probably beneficial for women with MS to use CHC regimens with longer estrogen periods and fewer pill-free intervals. Future studies should investigate the outcomes of such regimens on relapse rate, MRI lesions, disease activity related cytokines and chemokines in CSF and peripheral blood and the women's experiences of their symptoms. 


\section{LIST OF ORIGINAL PAPERS}

This thesis is based on the following publications and manuscripts, referred to in the text by their Roman numerals:

I

Holmqvist P*, Hammar M, Landtblom AM, Brynhildsen J. Symptoms of multiple sclerosis in women in relation to cyclical hormone changes. The European Journal of Contraception \& Reproductive Health Care. 2009;14(5):365-70.

II Kempe P*, Hammar M, Brynhildsen J. Symptoms of Multiple Sclerosis during use of Combined Hormonal Contraception. Submitted

III Holmqvist P*, Hammar M, Landtblom A-M, Brynhildsen J. Age at onset of multiple sclerosis is correlated to use of combined oral contraceptives and childbirth before diagnosis. Fertility and Sterility. 2010;94(7):2835-7.

IV Kempe $\mathbf{P}^{*}$, Eklund D, Hallin A, Hammar M, Olsson T, Brynhildsen J, Ernerudh J. T cell subset-associated transcription factors, cytokines and chemokines in relation to the menstrual cycle and use of combined hormonal contraceptives in women with multiple sclerosis and healthy controls. Manuscript

*Per Holmqvist changed family name to Kempe in 2011.

The published articles are reprinted with kind permissions from the publishers. 


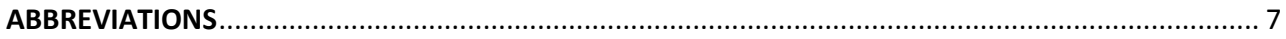

INTRODUCTION

BACKGROUND

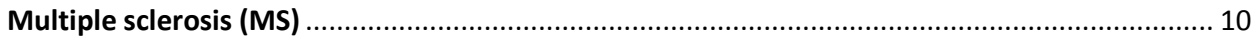

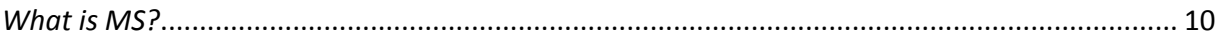

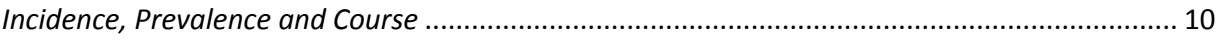

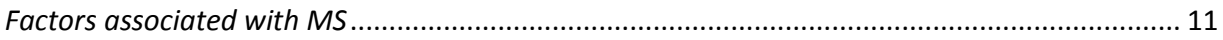

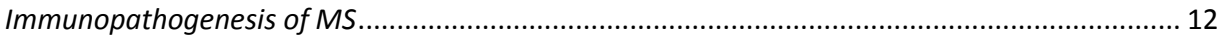

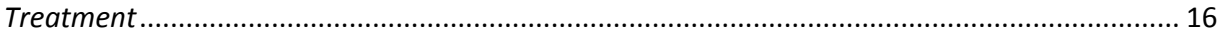

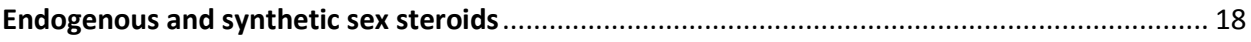

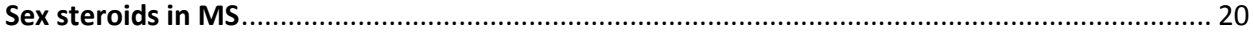

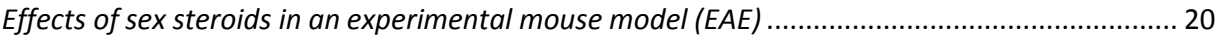

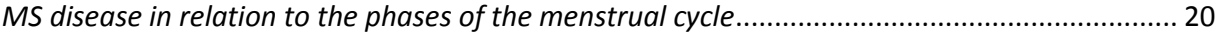

Association between MS disease and use of combined hormonal contraceptives ........................ 21

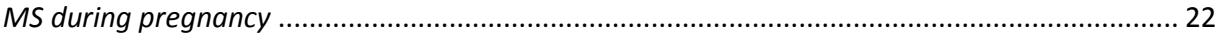

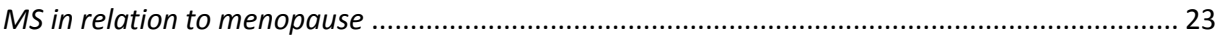

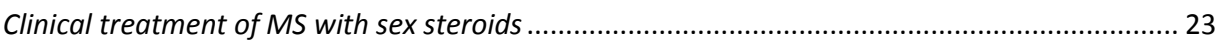

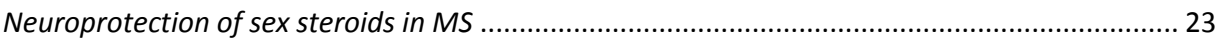

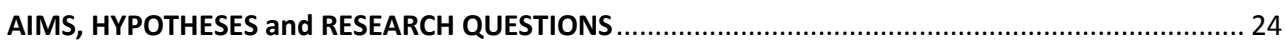

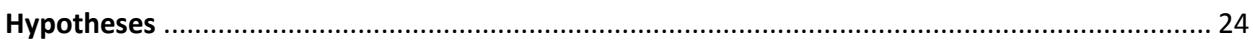

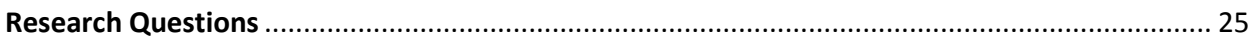

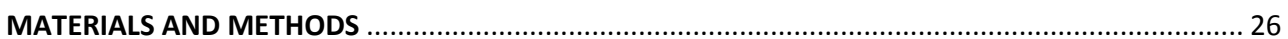

Do women with MS who do not use hormonal contraception have variations in symptom

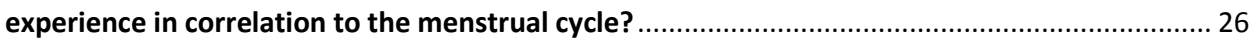

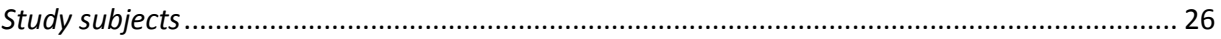

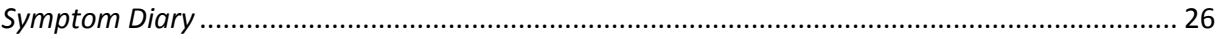

Do women with MS who use CHC experience more symptoms during the "pill-free" week, i.e.

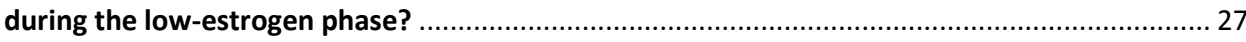

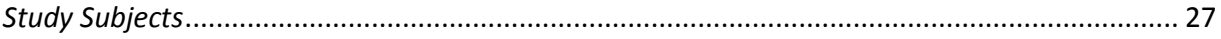

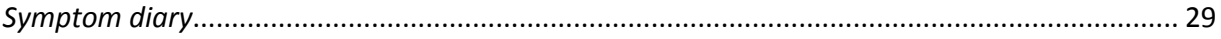

Are longer periods of exposure to high estrogen concentrations, such as $\mathrm{CHC}$-use and pregnancies before the onset of MS, related to age at onset of the disease? ............................... 30

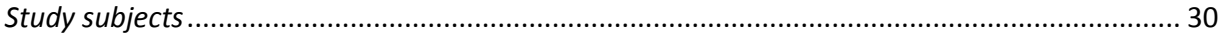

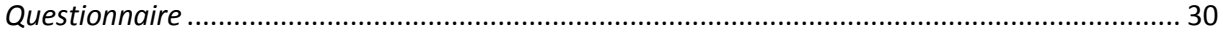


Do women with MS using CHC have fluctuations of peripheral blood concentrations of specific cytokines, chemokines and transcription factors related to different $\mathrm{T}$ cell subsets in relation to

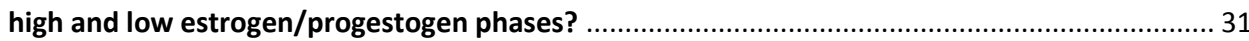

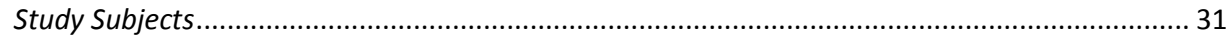

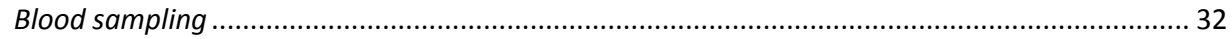

Multiplex Bead Assay for analyses of cytokines and chemokines ............................................... 33

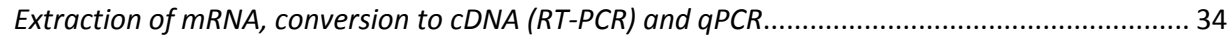

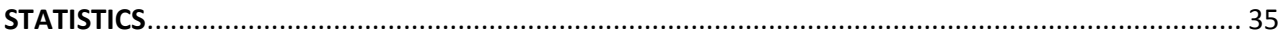

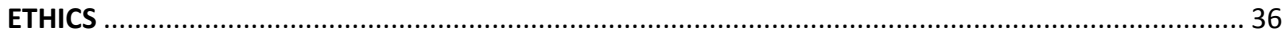

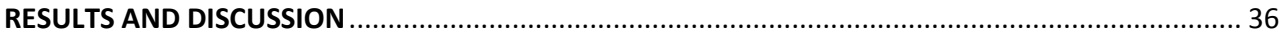

Do women with MS who do not use hormonal contraception have variations in symptom

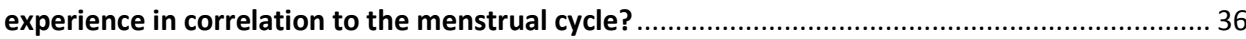

Do women with MS who use CHC experience more symptoms during the "pill-free" week, i.e. during the low-estrogen phase?

Are longer periods of exposure to high estrogen concentrations, such as $\mathrm{CHC}$-use and pregnancies before the onset of MS, related to age at onset of the disease?.......Fel! Bokmärket är inte definierat.

Do women with MS using CHC have fluctuations of peripheral blood concentrations of specific cytokines, chemokines and transcription factors related to different $\mathrm{T}$ cell subsets in relation to

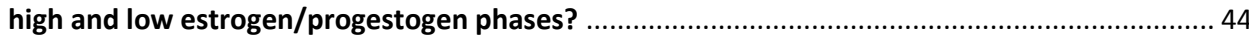

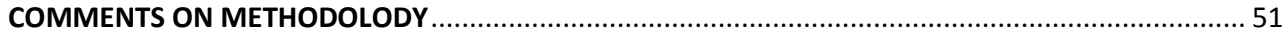

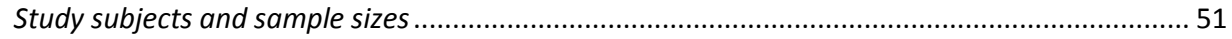

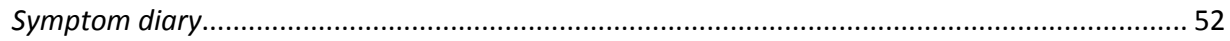

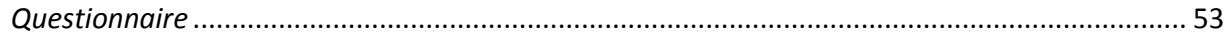

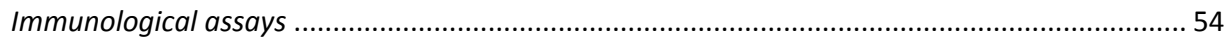

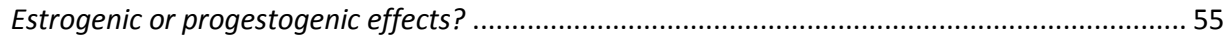

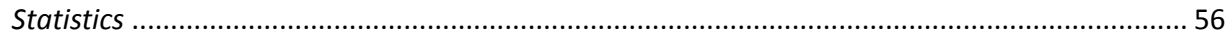

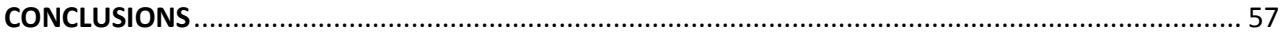

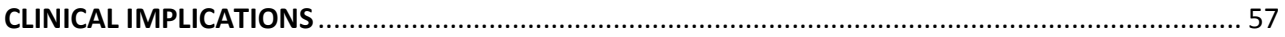

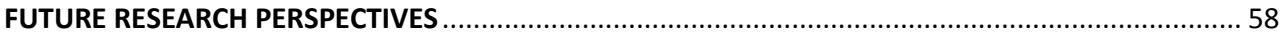

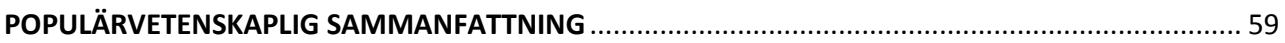

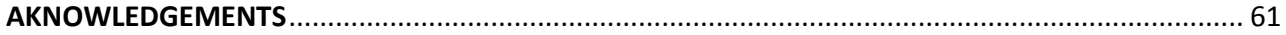

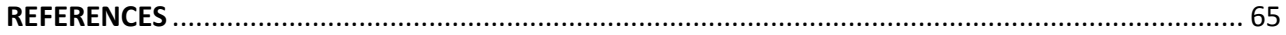

SUPPLEMENTS

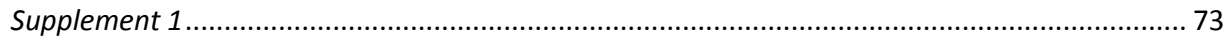

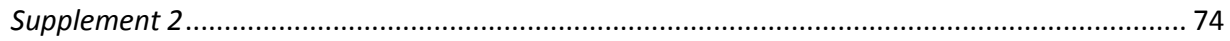

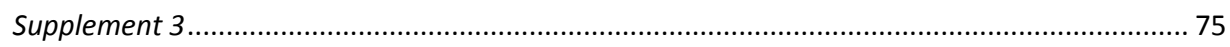

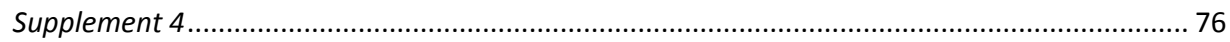




\section{ABBREVIATIONS in alphabetical order}

$\mathrm{Ab}=$ antibody

$\mathrm{Ag}=$ antigen

ANCOVA = analysis of covariance

ANOVA = analysis of variance

$\mathrm{APC}=$ antigen presenting cell

$\mathrm{BBB}=$ blood brain barrier

$\mathrm{C}=$ complement

CCL17 = chemokine $(\mathrm{C}-\mathrm{C}$ motif $)$ ligand 17

$\mathrm{CCL} 20=$ chemokine $(\mathrm{C}-\mathrm{C}$ motif $)$ ligand 20

CCL22 = chemokine ( $\mathrm{C}-\mathrm{C}$ motif $)$ ligand 22

$C D=$ cyclicity diagnoser

$\mathrm{CD} 3 \mathrm{E}=$ cluster of differentiation $3 \varepsilon$

CD4 = cluster of differentiation 4

CD8 = cluster of differentiation 8

CD 25 = cluster of differentiation 25

cDNA = complementary deoxyribonucleic acid

$\mathrm{CHC}=$ combined hormonal contraception

CNS = central nervous system

$\mathrm{COC}=$ combined oral contraceptive

CSF = cerebrospinal fluid

CXCL1 = chemokine $(\mathrm{C}-\mathrm{X}-\mathrm{C}$ motif $)$ ligand 1

CXCL8 = chemokine $(\mathrm{C}-\mathrm{X}-\mathrm{C}$ motif $)$ ligand 8

CXCL10 $=$ chemokine $(\mathrm{C}-\mathrm{X}-\mathrm{C}$ motif $)$ ligand 10

CXCL11 = chemokine (C-X-C motif) ligand 11

$\mathrm{CXCL13}=$ chemokine $(\mathrm{C}-\mathrm{X}-\mathrm{C}$ motif) ligand 13

CXCR5 = chemokine (C-X-C motif) receptor 5

$D C=$ dendritic cell

E1 = estrone

$E 2$ = estradiol
$\mathrm{E} 3$ = estriol

$E A E=$ experimental allergic encephalomyelitis

$E B V=$ epstein-barr virus

EDSS = expanded disability status scale

EDTA = ethylenediaminetetraacetic acid

$\mathrm{EE}=$ ethinyl estradiol

$E R \alpha=$ estrogen receptor $\alpha$

$E R \beta=$ estrogen receptor $\beta$

FoxP3 $=$ forkhead box P3

$\mathrm{FSH}=$ follicular stimulating hormone

GATA3 = GATA bindning protein 3

$\mathrm{GLM}=$ general linear model

GM-CSF = granulocyte-macrophage colonystimulating factor

$\mathrm{GnRH}=$ gonadotropin releasing hormone

GPER/GPR30 = G-protein coupled membrane related estrogen receptor

HLA = human leukocyte antigen

ICAM-1 = intercellular adhesion molecule 1

IFN- $\gamma=$ interferon $-\gamma$

IL-1 = interleukin 1

IL-1RA = interleukin 1 receptor antagonist

$\mathrm{IL}-2$ = interleukin 2

IL-2RA= interleukin 2 receptor alpha

IL-4 = interleukin 4

IL-5 = interleukin 5

IL-6 = interleukin 6

IL-7R = interleukin 7 receptor

IL-10 = interleukin 10

$\mathrm{IL}-12$ = interleukin 12 


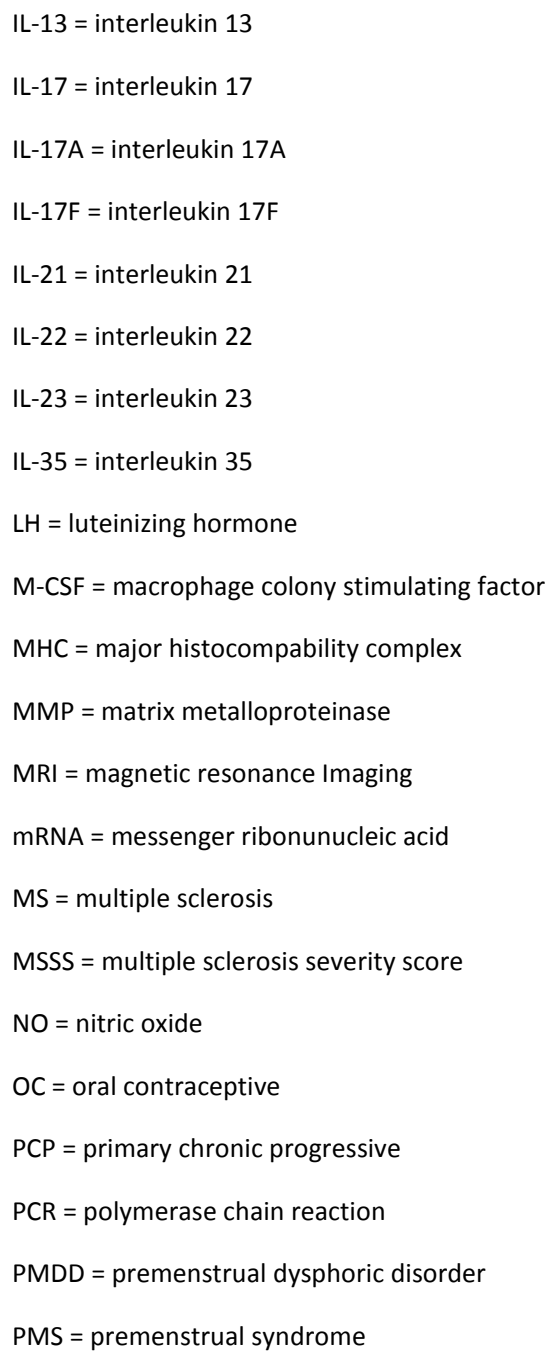

POP = progestin only pill

$\mathrm{PP}=$ primary progressive

qPCR = quantitative polymerase chain reaction

RORC $=$ RAR-related orphan receptor $\mathrm{C}$

ROR $\gamma \tau=$ RAR-related orphan receptor $\gamma \tau$

ROS = reactive oxygen species

RNA = ribonunucleic acid

$\mathrm{RR}=$ relapsing remitting

RT-PCR = reverse transcriptase polymerase chain reaction

$\mathrm{SD}=$ standard deviation

SMS register = Swedish MS register

$\mathrm{SP}=$ secondary progressive

STAT3 = signal transducer and activator of transcription 3

T-bet $=\mathrm{T}$-box gene expressed in T cells

TBX21 = T-box 21

Tc $=$ cytotoxic $T$ cell $(C D 8+)$

TGF- $\beta=$ transforming growth factor $-\beta$

Th $=$ T helper

TNF- $\alpha=$ tumor necrosis factor $\alpha$

Treg = regulatory $\mathrm{T}$ cell 


\section{INTRODUCTION}

Multiple Sclerosis (MS) is a severe neurological disease that strikes a woman during a period of her life when childbearing, breastfeeding and a reliable contraceptive method are important matters in her life. Previous studies indicate that sex steroids may affect the incidence, course and immunologic processes involved in MS. From this clinical viewpoint the questions were raised about the influence of the ovarian sex hormone cycle and combined hormonal contraception ( $\mathrm{CHC}$ ) on $\mathrm{MS}$ that in the end became the basis for the research leading to this thesis. 


\section{BACKGROUND}

\section{Multiple sclerosis (MS)}

\section{What is MS?}

MS is a chronic inflammatory disease of the central nervous system (CNS) that gives rise to various kinds of neurological symptoms such as sensory or motor symptoms or visual disturbances. MS typically makes its debut in young adults and leads to various degrees of neurological disability with time. MS is characterized by multifocal inflammation, demyelination, reactive gliosis and axonal loss.(1-3)

The myelin sheaths surrounding the axons of the neurons facilitate transmission of nerve impulses. Loss of the myelin sheaths leads to failure of the neurons to effectively conduct electric signals. As the name indicates MS affects various parts of the CNS and inflammatory lesions and sclerosed plaques are typical findings on magnetic resonance imaging.

Incidence, Prevalence and Course

The world-wide incidence of MS is 1.5-12.4 per 100,000 person-years in women and 0.9-7.0 in men according to several studies.(4) The prevalence in Sweden has been reported to be 189 per 100,000.(5) The incidence is two to three times higher in women and the incidence rises with latitude. $(4,6,7)$ The vast majority of patients diagnosed with MS have a relapsingremitting (RR) form of the disease characterized by periods of relapses, or exacerbations, with new or worsened symptoms. The relapses are followed by periods of remission, during which time the person recovers from the deficits acquired during the relapse. Eventually the disease evolves into a secondary progressive stage (SP) with a gradual progression of the neurological disability. About $15 \%$ of patients with MS have a progressive disease from the time of debut, called Primary Progressive (PP) MS, a form of the disease that is more frequent in men.(1) 
The etiology of MS is not fully known but both environmental and genetic factors have been identified. There is a $5 \%$ concordance among dizygotic twins and $25 \%$ concordance among monozygotic twins with a stronger concordance among female than male monozygotic twins.(8) Susceptibility to MS is associated with certain Human Leukocyte Antigen (HLA) alleles, the genes coding for the histocompatibility complex (MHC). Especially some genes and combinations of them (DRB1*1501, DQA1*0102 and DQB1*0602, i.e. HLA-DR15 haplotype) are related to a higher risk of developing MS.(9) Polymorphisms of non-HLA genes, such as the ones coding for the cytokine receptors IL-7R and IL-2RA, the adhesion molecule ICAM-1 and the transcription factor STAT3 also contribute to the risk of developing MS.(10)

Results from epidemiologic studies indicate that sex may influence the pathogenesis and course of MS suggesting that sex hormones may affect the disease. The incidence is higher among women than men $(4,6,7)$ and the disease course seems to differ between the sexes. Women more often follow a relapsing-remitting clinical development while men are more prone to get a more progressive disease with poor prognosis.(11, 12)

Earlier studies have shown an association between MS prevalence and living at high latitude although this association has been found to be weaker in more recent studies(4) According to this finding vitamin $D\left(1,25\right.$-dihydroxyvitamin $\left.D_{3}\right)$ and sunlight have been postulated to lower the risk of MS with independent effects.(13) A large case-control study showed lower Vitamin D levels among MS patients (14) than in healthy controls. An inverse correlation between Vitamin D levels and relapse rate has been shown (15) and high-dose vitamin D treatment has been suggested to reduce the risk of relapses.(16)

MS is a presumed autoimmune disease and viral triggers of the disease have been suggested although none has been proven. The Epstein-Barr virus (EBV) has received the most attention as an etiological factor for MS, and mononucleosis, caused by EBV, has a geographic distribution similar to that of MS. An increased prevalence of MS in patients with previous mononucleosis has been shown in a case-control study (17) and according to a meta-analysis the risk of MS is increased in an EBV-seropositive group compared with a 
seronegative population. The risk increases significantly if the patients are infected during childhood and especially high levels of antibodies against EBV nuclear antigen in combination with the HLA-risk type increases the risk for developing MS.(18)

Tobacco smoking is also associated with an increased risk of developing MS. This has been shown in both a case-control study (19) and in a cohort-study.(20) None of these studies found any correlation between moist tobacco and risk for developing MS, which may indicate that it is inhaled non-nicotine components of cigarette smoke and not the nicotine itself that is involved in the etiology of MS.

Immunopathogenesis of MS

Experimental Autoimmune Encephalomyelitis (EAE) is an important animal model for studying MS, and can be induced in rodents by immunization with myelin proteins with adjuvant or by adoptive transfer of myelin-specific $C D 4^{+} T$ helper cells.(21) Many of the immunological mechanisms that are thought to be parts of the pathogenesis of MS are studied in EAE. As with MS, EAE can have different courses. The exact mechanisms that determine why the immune system starts to react against the self-antigens and destroy the self-tissues are not known but there are many theories. It is possible that different mechanisms are variably important in different individuals and also that different mechanisms play important roles in various stages of MS and EAE. Nevertheless, EAE is still a very important model to be used in understanding the mechanisms in MS pathogenesis and for development of disease-modifying treatments.

The CD4+ Thelper (Th) cells are the conductors of the adaptive immune system in the way that, based on the type of threat, a specific Th cell subset will be activated, expand and signal to other specific effector cells of the immune system. A number of T cell subsets with function profiles have been identified. In the research for this thesis we have investigated the Th cell subsets (Figure 1) that are best known and characterized in relation to MS and sex steroids, the Th1 cells, the Th2 cells, the Th17 cells and the regulatory T cells (Tregs). 


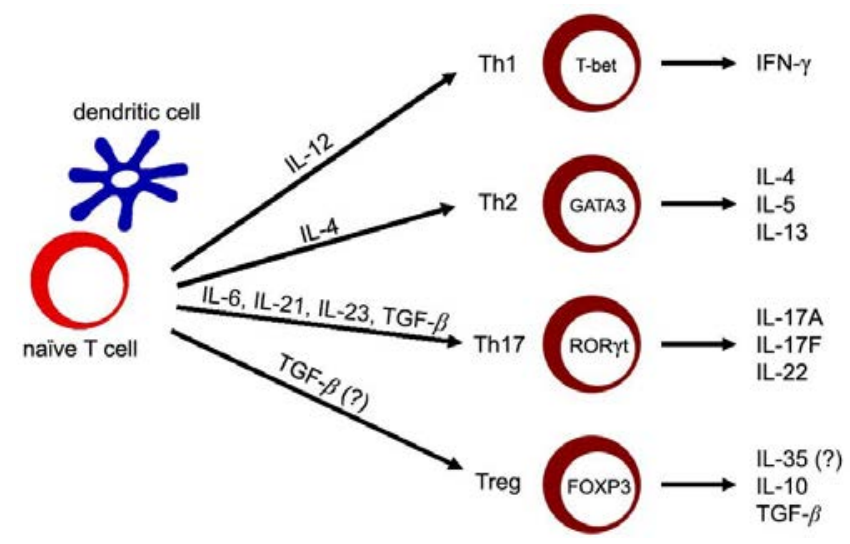

Figure 1. The Th cell subsets Th1, Th2, Th17 and Treg and their specific cytokines and transcription factors. Illustration reproduced by kind permission of Måns Edström

Each T cell subset is characterized by its profile ofcytokines, chemokines and transcriptions factors, although there are overlaps. The concentrations of cytokines, chemokines and transcription factors can be used to identify different subsets (Figure 1 and Table 1). (22)

Table 1. Characteristics of Th1, Th2, Th17 and Treg cells.

$\begin{array}{llll}\text { Th1 } & \text { Th2 } & \text { Th17 } & \text { Treg }\end{array}$

\begin{tabular}{|c|c|c|c|c|}
\hline Function & $\begin{array}{c}\text { Defence } \\
\text { against } \\
\text { intracellular } \\
\text { microbes }\end{array}$ & $\begin{array}{l}\text { Defence against } \\
\text { helminths }\end{array}$ & $\begin{array}{c}\text { Defence } \\
\text { against } \\
\text { extracellular } \\
\text { bacteria and } \\
\text { fungi }\end{array}$ & $\begin{array}{l}\text { Regulatory } \\
\text { function }\end{array}$ \\
\hline Main effects & $\begin{array}{l}\text { Activation of } \\
\text { macrophages }\end{array}$ & $\begin{array}{c}\text { Eosinophil } \\
\text { activation, } \\
\text { B cell activation } \\
\text { (IgE) }\end{array}$ & $\begin{array}{l}\text { Recruitment } \\
\text { of neutophils }\end{array}$ & Suppression \\
\hline Stimulated by & IL-12 & IL-4 & $\begin{array}{c}\text { IL-6, IL-21, IL- } \\
23, \text { TGF- } \beta\end{array}$ & TGF- $\beta$ \\
\hline Cytokines & IFN-,- GM-CSF & IL-4, IL-5, IL-13 & $\begin{array}{l}\text { IL-17A, IL- } \\
\text { 17F, IL-22 }\end{array}$ & $\begin{array}{c}\text { IL-35(?), TGF- } \\
\beta, \text { IL-10 }\end{array}$ \\
\hline Chemokines & $\begin{array}{l}\text { CXCL10, } \\
\text { CXCL11 }\end{array}$ & CCL17, CCL22 & $\begin{array}{c}\text { CXCL8, } \\
\text { CXCL1, CCL20 }\end{array}$ & \\
\hline $\begin{array}{l}\text { Transcription } \\
\text { factor }\end{array}$ & TBX21 & GATA3 & RORC & Foxp3 \\
\hline
\end{tabular}


Tolerance to self is a crucial step in the maturation of the adaptive immune system. During $T$ cell maturation in the thymus, only thymocytes with low or no avidity to self-peptides are allowed to develop into mature lymphocytes whereas thymocytes with high avidity are either deleted through apoptosis or differentiate into Tregs with specificity for these antigens. Tregs has several mechanisms to down-regulate actions of other Th cells. Despite this central tolerance, there are still mature T cells in the peripheral lymphoid organs that recognize self-antigens. Mechanisms of peripheral tolerance are therefore important to avoid activation of these self-reactive T cells, which could lead to autoimmune disease. For example naive CD4+ cells that recognize antigen without co-stimulation become anergic or evolve into Tregs.(22)

Autoreactive T cells, i.e cells that recognize self-antigens, as for example myelin-derived peptides, exists in healthy individuals (23) but most humans do not develop autoimmune disease. The activation of myelin-specific T-cells leading to MS is thought to take place in peripheral lymphoid organs, such as lymph nodes or the spleen. Recently, the lymphoid areas in the gut have been proposed to be of great importance for priming T-cells before entering the nervous system.(24) The events that trigger this activation are not clear but several possible mechanisms have been proposed. Infections, and viral infections especially, can be a part of this process in different ways. Molecular mimicry means that an epitope is shared between a microbial peptide and a self-peptide and hence a microbial peptide may trigger/activate an autoimmune disease. Bystander activation indicates a process where virus infections lead to activation of antigen presenting cells (APCs) which in turn may activate autoreactive T cells.(25) Whether the process starts with molecular mimicry, bystander activation or a combination of both, the destruction of tissue will result in presentation of new peptides that will be able to activate even more T cells in a process that may involve epitope spreading.(26) Activated T cells migrate to the CNS across the blood brain barrier (BBB) through binding of adhesion molecules on T cells to molecules on endothelial cells. Matrix metalloproteinases (MMPs) play an important role for the breakdown of extracellular matrix and ease migration of T cells and other cells into the CNS but do also contribute to demyelination and damage to axons. Cytokines will stimulate or inhibit activation of specific cells of the immune system and chemokines will take part in the regulation and direction of the cells into and inside the CNS.(27) Once inside the CNS the 
activated Th1 cells will stimulate activation of macrophages and CD8+ T cells through TNF- $\alpha$ and IFN- - . These will in turn release enzymes and more cytokines with harmful effects on myelin sheaths, oligodendrocytes and neurons.(28) CXCL13 attracts B cells which produce antibodies against myelin derived peptides and activate complement contributing to the tissue injury. Oxidative stress with production of reactive oxygen and nitrogen species is also thought to play an important role for neuronal cell death. Figure 2 shows a summarized model of MS immunopathogenesis. The neurological symptoms and radiological markers of MS are a result of inflammation, demyelination, gliosis and loss of axons. Sex steroids have been shown to be able to affect these processes in animal models. Today it is not known if use of $\mathrm{CHC}$ affects the immunological system in a way that could influence the immunopathogenesis of MS.

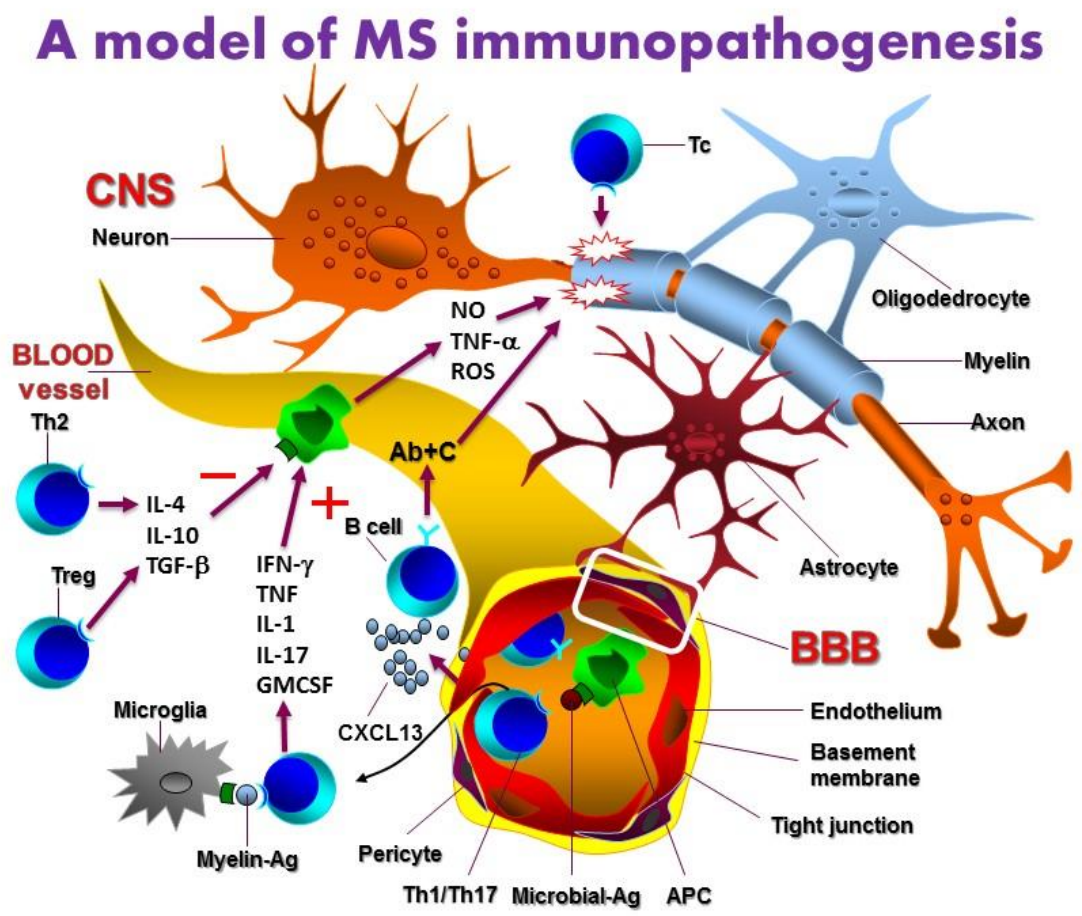

Figure 2. A summarized model of MS immunopathogenesis. Illustration reproduced by kind permission of Assistant Professor Mohsen Khademi. 


\section{Diagnostics}

The MS diagnosis based on clinical and radiological evidence of neuroinflammation according to the McDonald criteria (Table 2).(29) In the cerebrospinal fluid (CSF) slightly elevated numbers of mononuclear cells and signs of antibody production within the CNS are typical findings supporting the diagnosis. Magnetic Resonance Imaging (MRI) is the most important radiological method for diagnosing and monitoring the course of the disease. New techniques of MRI have been developed during the last decades to better monitor inflammation and neurodegeneration. $(30,31)$

\section{Treatment}

During the last 20 years several immunmodulatory treatments have been developed and are now offered to all individuals with RRMS. These treatments decrease the inflammatory activity in CNS to various degrees. Unfortunately, there is still no treatment affecting the progressive form of the disease where more degenerative mechanisms prevail. Corticosteroids are used for symptom relief at the time of exacerbations but they do not decrease the frequency of exacerbations. The most common immunomodulatory drugs used in MS are IFN- $\beta$ and Glatiramer Acetate, which reduce the frequency of new episodes by $30 \%$. Local reactions at the injection site and flu-like symptoms are common side effects. In IFN- $\beta$ treated patients, the development of neutralizing antibodies may take place and abolish the effect of the treatment. Newer drugs include the monoclonal antibodies natalizumab blocking the passage of immune cells over the blood brain barrier and the oral drug fingolimod that leads to pronounced lymphopenia. (2) The immunomodulatory treatments effectively downregulate the inflammatory activity in MS, so it would therefore be unethical to withdraw this type of drugs during studies of the effects of sex steroids. 
Table 2. The 2010 McDonald Criteria for diagnosing MS (29)

Clinical Presentation

$\geq 2$ attacks ${ }^{a}$, objective clinical

evidence of $\geq 2$ lesions or objective

clinical evidence of 1 lesion with

reasonable historical

evidence of a prior attack

$\geq 2$ attacks ${ }^{\mathrm{a}}$, objective clinical

evidence of 1 lesion

1 attack $^{\mathrm{a}}$, objective clinical

evidence of $\geq 2$ lesions

1 attack $^{\mathrm{a}}$, objective clinical

evidence of 1 lesion

(clinically isolated syndrome)
Dissemination in space, demonstrated by: $\geq 1$ T2 lesion in at least 2 of

4 MS-typical regions of the CNS (periventricular, juxtacortical,

infratentorial, or spinal cord) ${ }^{d}$, or Await a further clinical attack ${ }^{a}$, implicating a different CNS site

Dissemination in time, demonstrated by: Simultaneous presence of asymptomatic gadolinium-enhancing and nonenhancing lesions at any time; or

A new T2 and/or gadolinium-enhancing lesion(s) on follow-up. MRI, irrespective of its timing with reference to a baseline scan; or Await a second clinical attack ${ }^{\mathrm{a}}$

Dissemination in space and time, demonstrated by:

For DIS:

$\geq 1$ T2 lesion in at least 2 of 4 MS-typical regions of the CNS (periventricular, juxtacortical, infratentorial, or spinal cord) ${ }^{\mathrm{d}}$, or Await a second clinical attack ${ }^{\mathrm{a}}$ implicating a different CNS site; and For DIT:

Simultaneous presence of asymptomatic gadolinium-enhancing and nonenhancing lesions at any time; or

A new T2 and/or gadolinium-enhancing lesion(s) on follow-up MRI, irrespective of its timing with reference to a baseline scan; or Await a second clinical attack ${ }^{a}$

1 year of disease progression (retrospectively or prospectively determined) plus 2 of 3 of the following criteriad:

1. Evidence for DIS in the brain based on $\geq 1 \mathrm{~T} 2$ lesions in the MS-characteristic (periventricular, juxtacortical, or infratentorial) regions

2. Evidence for DIS in the spinal cord based on $\geq 2 \mathrm{~T} 2$ lesions in the cord

3. Positive CSF (isoelectric focusing evidence of oligoclonal bands and/or elevated IgG index)

If the Criteria are fulfilled and there is no better explanation for the clinical presentation, the diagnosis is "MS", if suspicious, but the Criteria are not completely met, the diagnosis is "possible MS" if another diagnosis arises during the evaluation that better explains the clinical presentation, then the diagnosis is "not MS."

a An attack (relapse, exacerbation) is defined as patient-reported or objectively observed events typical of an acute

inflammatorydemyelinating event in the CNS, current or historical, with duration of at least 24 hours, in the absence of fever or infection. It should be documented by contemporaneous neurological examination, but some historical events with symptoms and evolution characteristic for MS, but for which no objective neurological findings are documented, can provide reasonable evidence of a prior demyelinating event. Reports of paroxysmal symptoms (historical or current) should, however, consist of multiple episodes occurring over not less than 24 hours. Before a definite diagnosis of MS can be made, at least 1 attack must be corroborated by findings on neurological examination, visual evoked potential response in patients reporting prior visual disturbance, or MRI consistent with demyelination in the area of the CNS implicated in the historical report of neurological symptoms.

bClinical diagnosis based on objective clinical findings for 2 attacks is most secure. Reasonable historical evidence for 1 past attack, in the absence of documented objective neurological findings, can include historical events with symptoms and evolution characteristics for a prior inflammatory demyelinating event, at least 1 attack, however, must be supported by objective findings.

cNo additional tests are required. However, it is desirable that any diagnosis of MS be made with access to imaging based on these Criteria. If imaging or other tests (for instance, CSF) are undertaken and are negative, extreme caution needs to be taken before making a diagnosis of MS, and alternative diagnoses must be considered. There must be no better explanation for the clinical presentation, and objective evidence must be present to support a diagnosis of MS.

${ }^{\mathrm{d}}$ Gadolinium-enhancing lesions are not required, symptomatic lesions are excluded from consideration in subjects with brainstem or spinal cord syndromes.

MS = multiple sclerosis, CNS = central nervous system, MRI = magnetic resonance imaging, DIS = dissemination in space, DIT = dissemination in time, $\mathrm{PPMS}=$ primary progressive multiple sclerosis, $\mathrm{CSF}=$ cerebrospinal fluid, $\mathrm{IgG}=$ immunoglobulin $\mathrm{G}$. 


\section{Endogenous and synthetic sex steroids}

Sex steroids are a wide group of natural or synthetic hormones which all share the same structural steroid skeleton but that have divergent effects. Estrogens are important sex steroids naturally produced by the ovaries during the ovulatory cycle in the form of $17 \beta$ estradiol (E2) and estrone (E1) and by the placenta during pregnancy mainly in the form of estriol (E3). Estrogens bind to the intranuclear estrogen receptors $\alpha(E R \alpha)$ and $E R \beta$ which act like transcription factors by regulating the expression of different genes.(32) Estrogens also bind to a membrane bound receptor called G-protein coupled Estrogen Receptor (GPER) which mediates faster, non-genomic, processes than the nucleic receptors do.(33) The different estrogens have different potencies measured as effects on FSH levels, liver proteins and bone density depending on bioavailability, receptor affinity and the length of time the estrogen-receptor-complex is actually in the cell nucleus.(22) The low potent E3 has been suggested to be 8-10 times less potent than E2. The synthetic estrogen ethinyl estradiol (EE) on the other hand, has been suggested to be about 100-500 times more potent than E2.(22, 34) The plasma level of E2 during the normal menstrual cycle peaks at $330-700 \mathrm{pg} / \mathrm{ml}$ in late follicular phase and falls below $50 \mathrm{pg} / \mathrm{ml}$ at menstruation. The plasma level of EE is $90-130$ $\mathrm{pg} / \mathrm{ml} 1-2 \mathrm{hours}$ after oral administration of a $30 \mu \mathrm{g}$ dose. Due to first pass metabolism in the liver the bioavailability of orally administered EE only is around 45\%.(35) Taken together, combined oral contraceptives with EE doses of 20-30 $\mu \mathrm{g}$ give a constant estrogen stimulation that could be estimated to be around 20-100 times higher than the effect of E2 in late follicular phase of a normal menstrual cycle or 3-4 times the potency of E2 and E3 together in late pregnancy. After ovulation the follicle develops into a corpus luteum which produces not only estrogens but also the sex steroid progesterone with numerous effects. Endogenous progesterone and synthetic compounds with affinity to the progesterone receptor are together referred to as progestogens in this thesis.

Oral contraceptives may contain only a progestogen, a Progestin Only Pill (POP), or a combination of estrogen and a progestogen (combined oral contraceptives, COC). Both oral, transdermal and vaginally administered combinations of estrogens and progestogens exist, and in this thesis the term Combined Hormonal Contraception $(\mathrm{CHC})$ includes all administration routes. The estrogen in most $\mathrm{CHC}$ is $\mathrm{EE}$, but recently $\mathrm{CHC}$ containing $\mathrm{E} 2$ has 
been introduced. The most common $\mathrm{CHC}$ regimen is 21 days of hormone-containing pills and seven days of hormone-free pills or pill free days. There are also regimens with shorter hormone-free periods.

The menstrual cycle is subdivided into the follicular phase and the luteal phase with the event of ovulation separating the two. The regulation of the menstrual cycle is an intricate system of positive- and negative feedback pathways of ovarian sex steroids, the pituitary derived peptide hormones Follicular Stimulating Hormone (FSH) and Luteinizing Hormone $(\mathrm{LH})$, and Gonadotropin Releasing Hormone ( $\mathrm{GnRH}$ ) produced from the hypothalamus, extensively described for example by Speroff. (36) As shown in Figure 3, the concentrations of E2 and progesterone in the blood vary significantly during the menstrual cycle with low levels of progesterone during the follicular phase and high levels in the luteal phase whereas E2 has a biphasic concentration pattern. Women using $\mathrm{CHC}$, on the other hand, have a fairly steady supraphysiologic concentration of the highly potent EE and a progestogen during 21 days and then seven days without delivery of these hormones.

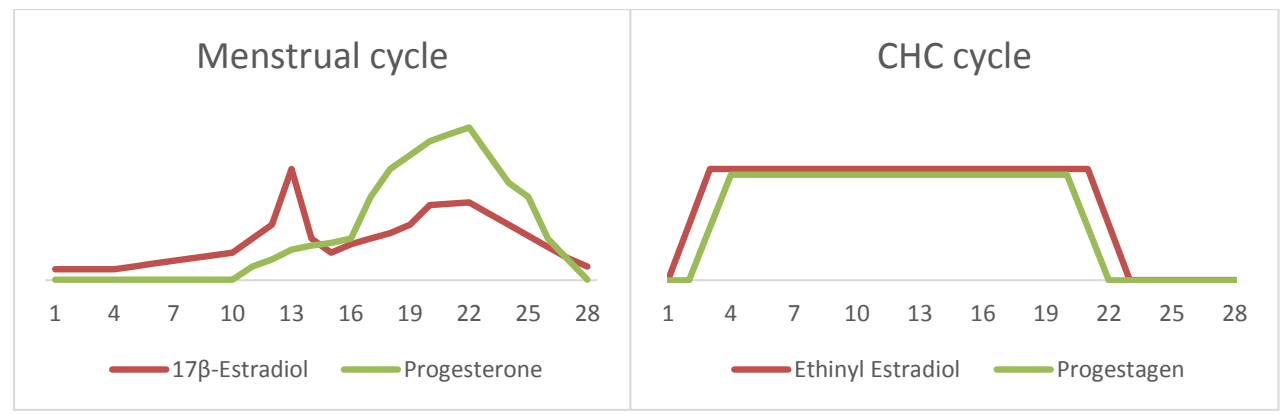

Figure 3. Schematic presentation of sex steroid concentrations during the menstrual cycle versus the $\mathrm{CHC}$ controlled cycle. 


\section{Sex steroids in MS}

Effects of sex steroids in an experimental mouse model (EAE)

Because the incidence and disease activity seem to be related to sex steroid levels, treatment with sex steroids has been studied in the mouse model of MS, EAE. Administration of E2 before induction of EAE has been found to protect against the development of the myelitis.(37-40) This effect has been shown to be mediated both through Era $(38,41)$ and GPER.(39) Administration of E2 has not been shown to reduce the severity of EAE after onset. However, this effect has been achieved using either an ER $\alpha$ selective ligand $(42)$ or EE. $(43,44)$ The effects of EE seem to be mediated by GPER rather than ER $\alpha .(44)$ In EAE studies, the positive effects of estrogens or selective estrogen receptor ligands have been related to lower expression of TNF- $\alpha$, IFN- - , IL- 6 and IL-2 and higher expression of IL-13 and TGF- $\beta$ whereas divergent results have been shown for IL-5 and IL-10 in different studies. $(37,40-43,45)$. It has also been shown that the protective effect of E2 involves estrogenic stimulation of Dendritic Cells (DC) and B cells. This may lead to negative co-stimulatory signaling and up-regulation of FoxP3+ regulatory T cells (Tregs).(40, 46-48) Progesterone has also been shown to be able to reduce the severity of EAE with decreased expression of IL-2 and IL-17 and increased expression of IL-10. $(49,50)$

MS disease in relation to the phases of the menstrual cycle

Differences in MS symptoms in relation to the menstrual cycle have been studied in small retrospective studies showing that women with MS experienced more MS symptoms in the premenstrual phase $(51,52)$ and had exacerbations of MS starting in the premenstrual period.(53) Smith and Studd reported that nine out of 11 women in fertile age with regular menstrual bleedings had a premenstrual increase in symptom experience.(51) Zorgdrager et al found that $43 \%$ of 60 women with the RR-type experienced worsening of symptoms in the premenstrual period, whereas none of the 12 women with the primary chronic progressive (PCP)-type reported changed MS-symptoms related to the menstrual cycle.(52) In another retrospective study by the same authors $42 \%$ of 56 women had exacerbations of MS starting 
in the premenstrual period.(53) This could be a result of sex steroid-induced cytokine changes that have been shown to occur in relation to the menstrual cycle.(54) Changes in disease activity on MRI scans have also been shown to be related to female steroid sex hormone variation during the menstrual cycle although the results are partially contradictory. $(55,56)$ Studies have reported a higher ratio of Tregs to all CD4+ cells in the late follicular phase of the menstrual cycle than in the luteal phase in peripheral blood of healthy fertile women. The Treg proportion was also correlated to the estradiol levels.(57) No study has been published using prospective registration of MS symptoms in relation to the different phases of the menstrual cycle.

\section{Association between MS disease and use of combined hormonal contraceptives}

Two cohort studies found no effect of oral contraceptives on the incidence of MS, although the type of oral contraceptive was not specified. $(58,59)$ A recently published study with a clear definition of $\mathrm{CHC}$ showed no difference in age at onset between women who had been using $\mathrm{CHC}$ before onset of MS and women who had not.(60) In a case-control study the incidence of MS was lower among users than non-users of CHC.(61) Two studies have shown that women with relapsing-remitting MS, who used oral contraceptives after disease onset, had a more benign disease course than the women who did not use CHC. $(60,62)$ Another study found, however, a higher risk of reaching a more severe state of MS among users of oral contraceptives in the subgroup of women with progressive onset MS.(63) The previous published studies of MS in relation to $\mathrm{CHC}$ use are summarized in Table 3. To our knowledge, no prospective studies of the effects of $\mathrm{CHC}$ on MS have been carried out and a general problem in many of the previous retrospective studies is the lack of a description of the contents of the oral contraceptives. 
Table 3. Summary of previous studies regarding the possible effects of $\mathrm{CHC}$ and oral contraceptives on MS incidence and disease course.

\begin{tabular}{|c|c|c|c|}
\hline Author (ref nr) & Study design & $\begin{array}{l}\text { Study } \\
\text { subjects }\end{array}$ & Main results \\
\hline Thorogood 1998 (59) & $\begin{array}{l}\text { Cohort study, } 28 \\
\text { years follow-up. }\end{array}$ & $\begin{array}{l}46,000 \\
\text { women }\end{array}$ & $\begin{array}{l}\text { No difference in MS incidence among ever-users of oral } \\
\text { contraceptives in comparison to never-users }\end{array}$ \\
\hline Hernan 2000 (58) & $\begin{array}{l}2 \text { cohort studies, } 18 \\
\text { and } 8 \text { years follow-up. }\end{array}$ & $\begin{array}{l}238,000 \\
\text { women }\end{array}$ & $\begin{array}{l}\text { No difference in MS incidence among ever-users of oral } \\
\text { contraceptives in comparison to never-users }\end{array}$ \\
\hline Alonso 2005 (61) & $\begin{array}{c}\text { Case-control study, } 3 \\
\text { years. }\end{array}$ & $\begin{array}{l}106 \text { cases, } \\
1001 \\
\text { controls }\end{array}$ & $\begin{array}{l}\text { The odds ratio for MS was } 0.6 \text { ( } 95 \% \text { confidence interval } \\
0.4-1.0 \text { ) in oral contraceptive users compared with } \\
\text { non-users during the previous } 3 \text { years }\end{array}$ \\
\hline Sena 2012 (62) & Cross-sectional & 132 & $\begin{array}{l}\text { More benign disease course among women who had } \\
\text { used oral contraceptives after onset of MS in } \\
\text { comparison to women who had not. }\end{array}$ \\
\hline D'Hooghe 2012 (63) & Cross-sectional & 973 & $\begin{array}{l}\text { Faster disease progression in women with SPMS using } \\
\text { oral contraceptives in comparison to non-users. No } \\
\text { difference shown in women with RRMS. }\end{array}$ \\
\hline Gava 2014 (60) & Cross-sectional & 174 & $\begin{array}{l}\text { COC users had lower disease scores in women who had } \\
\text { prior or current immunomodulatory treatment. Nonuse } \\
\text { of COCs was a predictor of disease evolution to SPMS. }\end{array}$ \\
\hline
\end{tabular}

\section{MS during pregnancy}

During the third trimester of pregnancy both clinical symptoms and relapse rate of MS seem to decrease while the post-partum period is associated with a risk of exacerbation of the disease.(64-69) Studies regarding breast-feeding and its possible influence on MS have resulted in contradictory results. $(69,70)$ Parity has been related to bot lower incidence of MS and more favorable long-term progression of the disease. $(63,71-73)$ The amelioration of MS during pregnancy is associated with several changes of the immune system. These include a relative rise in the activity of Th2 and regulatory T cell (Treg) T cell subsets compared with the activity of the Th17 and Th1 subsets. Previous studies suggest that this is a result of very high levels of estrogens and progesterone but also of other hormones such as 1,25-dihydroxy-vitamin D3, norepinephrine and cortisol.(74-78) 
The effect of the menopause on MS has been studied retrospectively with questionnaires and about $50 \%$ of the women with MS reported worsening of symptoms after menopause. The results regarding changes of MS symptoms in relation to use of HRT are divergent.(51, 79)

Clinical treatment of MS with sex steroids

Since the low potent estrogen estriol (E3) reaches high serum concentrations during pregnancy, when MS symptoms usually decrease, E3 has been tried as treatment of MS. In two studies of women with MS, treatment with E3 was associated with a reduction of enhancing lesions on MRI scans. $(80,81)$ Simultaneously, expression of Th2 and Treg associated cytokines increased and the pro-inflammatory cytokine TNF- $\alpha$ decreased in one of the studies (81) whereas the Th1 associated cytokine IFN- $\gamma$ decreased in the other.(80)

Neuroprotection of sex steroids in MS

Beside the potential effects of sex steroids on MS immunopathology, these hormones also seem to have neuroprotective effects independent of the immune system. These include prevention of oligodendrocyte damage and regulation of myelination.(82) 


\section{AIMS, HYPOTHESES and RESEARCH QUESTIONS}

MS is a severe inflammatory neurological disease of presumed autoimmune origin and affects women to a larger extent than men. The incidence of MS is highest between 20 and 40 years of age. This is an essential phase of a woman's life when she is often either pregnant, breastfeeding or needs a reliable contraceptive method. Sex steroids in general and estrogens in particular seem to have effects on the incidence and course of EAE and the immunological processes that are involved. The synthetic estrogen $E E$, which has been shown to be the most potent estrogen regarding effects on $E A E$, is also the most common estrogen in $\mathrm{CHC}$. On this background, the general aim of the research on which this thesis is based was to assess possible effects of sex steroid exposure in general, and the use of $\mathrm{CHC}$ in particular, on MS. These specific hypotheses and research questions were chosen:

\section{Hypotheses}

- MS in women is affected by variations in estrogen concentration which should be reflected during the menstrual cycle and during use of $\mathrm{CHC}$.

- Women with MS have variations in symptom experience in relation to the menstrual cycle.

- Women with MS who use CHC experience more symptoms during the "pillfree" week, i.e. during the low-estrogen/progestogen phase.

- Longer periods of exposure to high estrogen concentration, such as use of $\mathrm{CHC}$ and the occurrence of pregnancies before the onset of MS may postpone the age at onset of the disease.

- Women with MS using CHC have fluctuations of peripheral blood concentrations of specific cytokines, chemokines and transcription factors related to different $\mathrm{T}$ cell subsets in relation to high and low estrogen/progestogen phases. 


\section{Research Questions}

- Do women with MS who do not use hormonal contraception have variations in symptom experience related to the phases of the menstrual cycle?

- Do women with MS who use $\mathrm{CHC}$ experience more symptoms during the "pill-free" week, i.e. during the low-estrogen/progestogen phase than during the weeks with $\mathrm{CHC}$ ?

- Are exposures to high estrogen concentrations for longer periods such as $\mathrm{CHC}$-use and pregnancies before the onset of MS related to a higher age at onset of the disease?

- Do women with MS using $\mathrm{CHC}$ have fluctuations of peripheral blood concentrations of specific cytokines, chemokines and transcription factors related to different $\mathrm{T}$ cell subsets in relation to high and low estrogen/progestogen phases?

Table 4. Summary of the research questions, materials and methods for each of the four papers.

Paper I

\begin{tabular}{|c|c|c|c|c|}
\hline & Paper I & Paper II & Paper III & Paper IV \\
\hline $\begin{array}{l}\text { Research } \\
\text { Question }\end{array}$ & $\begin{array}{l}\text { Do women with MS who do } \\
\text { not use hormonal } \\
\text { contraception have } \\
\text { variations in symptom } \\
\text { experience related to the } \\
\text { phases of the menstrual } \\
\text { cycle? }\end{array}$ & $\begin{array}{l}\text { Do women with MS who } \\
\text { use CHC experience more } \\
\text { symptoms during the } \\
\text { "pill-free" week, i.e. } \\
\text { during the low- } \\
\text { estrogen/progestogen } \\
\text { phase than during the } \\
\text { weeks with CHC? }\end{array}$ & $\begin{array}{l}\text { Are exposures to } \\
\text { high estrogen } \\
\text { concentration for } \\
\text { longer periods such } \\
\text { as CHC-use and } \\
\text { pregnancies before } \\
\text { the onset of MS } \\
\text { related to a higher } \\
\text { age at onset of the } \\
\text { disease }\end{array}$ & $\begin{array}{l}\text { Do women with MS using } \\
\text { CHC have fluctuations of } \\
\text { peripheral blood } \\
\text { concentrations of specific } \\
\text { cytokines, chemokines and } \\
\text { transcription factors related } \\
\text { to different T cell subsets in } \\
\text { relation to high and low } \\
\text { estrogen/progestogen } \\
\text { phases? }\end{array}$ \\
\hline Material & $\begin{array}{l}16 \text { women without } \mathrm{CHC} \text { and } \\
7 \text { women with } \mathrm{CHC} \text {, all with } \\
\mathrm{MS}\end{array}$ & $\begin{array}{l}22 \text { women with } \mathrm{MS} \text { using } \\
\mathrm{CHC}, 7 \text { women with MS } \\
\text { without } \mathrm{CHC}, 10 \text { healthy } \\
\text { women with } \mathrm{CHC} \text {, and } 4 \\
\text { healthy women without } \\
\mathrm{CHC}\end{array}$ & 770 women with MS & $\begin{array}{l}12 \text { women with } \mathrm{MS} \text { using } \\
\mathrm{CHC}, 13 \text { women with } \mathrm{MS} \\
\text { without } \mathrm{CHC}, 13 \text { healthy } \\
\text { women with } \mathrm{CHC} \text {, and } 9 \\
\text { healthy women without } \\
\mathrm{CHC}\end{array}$ \\
\hline Method & Prospective symptom Diary & $\begin{array}{l}\text { Prospective symptom } \\
\text { Diary }\end{array}$ & Questionnaire & $\begin{array}{l}\text { Multiplex Bead Assay for } \\
\text { analyses of cytokines and } \\
\text { chemokines, quantitative } \\
\text { PCR for analyses of } \\
\text { transcription factors }\end{array}$ \\
\hline
\end{tabular}




\section{MATERIALS AND METHODS}

Do women with MS who do not use hormonal contraception have variations in symptom experience in correlation to the menstrual cycle? (Paper I)

Study subjects

Forty nine women with MS, who had regular menstrual cycles (21 to 35 days), were not using hormonal contraception, and had agreed to participate in this study were recruited from local MS-registers in Östergötland and Västernorrland counties. Sixteen of the 49 women with regular menstrual cycles, and without hormonal contraception, completed the diaries and were included in the analyses.

Symptom Diary

The symptom diary designed for paper I (supplement 1 ) included 13 symptoms of MS. The symptoms were suggested by an experienced clinical neurologist at the Department of Neurology at the University Hospital of Linköping, Sweden. For each day during three consecutive menstrual cycles the patient graded each symptom in four grades $(0=$ no symptom, 1 = mild symptom, 2 = moderate symptom, 3 = serious symptom). The woman also reported in the diary which days she had menstrual bleeding.

The spontaneous menstrual cycles of women not using hormonal contraception were divided into three phases as shown in Figure 4. For each phase and symptom the mean scores per day over three menstrual cycles were calculated. 


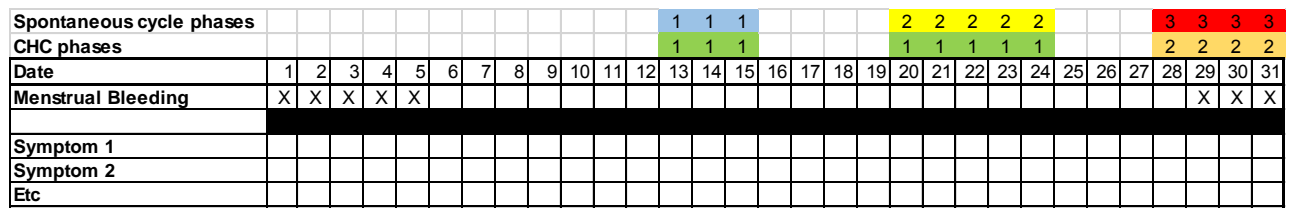

Figure 4. Schematic definition of the phases compared in the statistical analysis of paper I. For women with spontaneous menstrual cycles, the phases were defined as: phase 1- day 15 to day 13 before the start of the menstrual bleeding (high estrogen/low progesterone phase (blue), phase 2 day 9 to day 5 before the start of menstrual bleeding (high estrogen and progesterone phase) (yellow), phase 3 - the day before the start of menstrual bleeding until the third day of menstrual bleeding (low estrogen and progesterone phase) (red). For women using CHC two phases were compared (green and orange).

Do women with MS who use CHC experience more symptoms during the "pill-free" week, i.e. during the low-estrogen/progestogen phase? (Paper II)

\section{Study Subjects}

Five of the 49 women who returned the diary described in paper I had been using CHC during the study period. An analysis of these five diaries showed significant differences in symptom scores between CHC-phase and non-CHC-phase for two of the symptoms and thus we wanted to add more women using $\mathrm{CHC}$ to the study. We then used medical records to identify women with MS using $\mathrm{CHC}$ and sent out diaries to another 14 women of which two returned the diary. Altogether, seven women using a $\mathrm{CHC}$ were included in the statistical analyses.

In paper II, 521 women 18 to 45 years old, who had all participated in the study in which paper III is based on, were asked in a letter if they were using $\mathrm{CHC}$, and, if that was the case, if they could participate and fill out a symptom diary during three $\mathrm{CHC}$ cycles. Two-hundred and forty women responded and of these 17 used $\mathrm{CHC}$ and agreed to take part and were thus included in the study. One woman was excluded because of an exacerbation of her MS during the study period. Since the response rate and the use of $\mathrm{CHC}$ among the responders were very low we also included six women participating in the study of immunological changes during $\mathrm{CHC}$ and menstrual cycles (Paper IV) who had filled out the symptom diary. Comparison groups were women with MS without hormonal contraception and healthy 
women with and without $\mathrm{CHC}$. The women in these comparison groups also participated in the study on immunological changes in relation to fluctuations of sex hormones (paper IV). No woman who had participated in the earlier study using almost the same method as in the present study participated in this study. Thus, in total, diaries from 22 women with MS using $\mathrm{CHC}, 7$ women with MS without hormonal contraception, 10 healthy women using $\mathrm{CHC}$ and four healthy women without hormonal contraception were included in the statistical analyses (Figure 5).

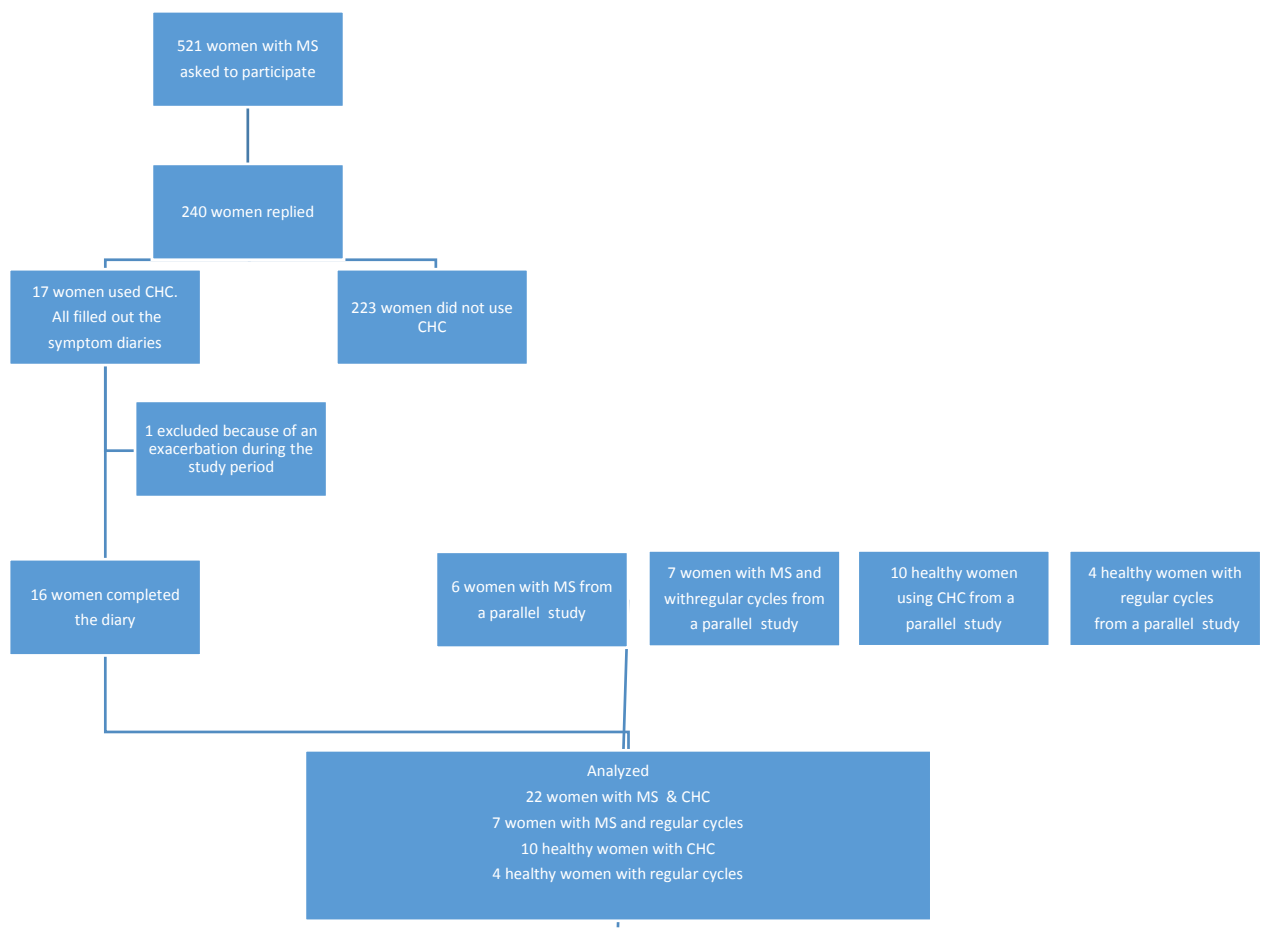

Figure 5. Flow-chart describing the women included in paper II. 


\section{Symptom diary}

In the research for paper II we used a modified diary based on the Cyclicity Diagnoser (CD) which is a validated instrument designed to measure menstrual cycle related symptom changes. (83) The diary used by CHC users is shown in supplement 2 and the diary used by women without hormonal contraception is shown in supplement 3 . The CD was originally designed for studies of premenstrual syndrome (PMS) and premenstrual dysphoric disorder (PMDD) symptoms and in the present study included 10 symptoms of MS (same as in paper I but excluding tiredness, mood and behavioral changes). The women were asked to grade each symptom from 1 (no symptom-experience) to 8 (maximal symptom-experience). The women also reported bleeding days in the diary and women using $\mathrm{CHC}$ also reported forgotten $\mathrm{CHC}$ tablets. The phases of the cycle compared in paper II were defined as shown in Figure 6. The phases of the cycles of the seven women with $\mathrm{CHC}$ described in paper I are shown in Figure 4.

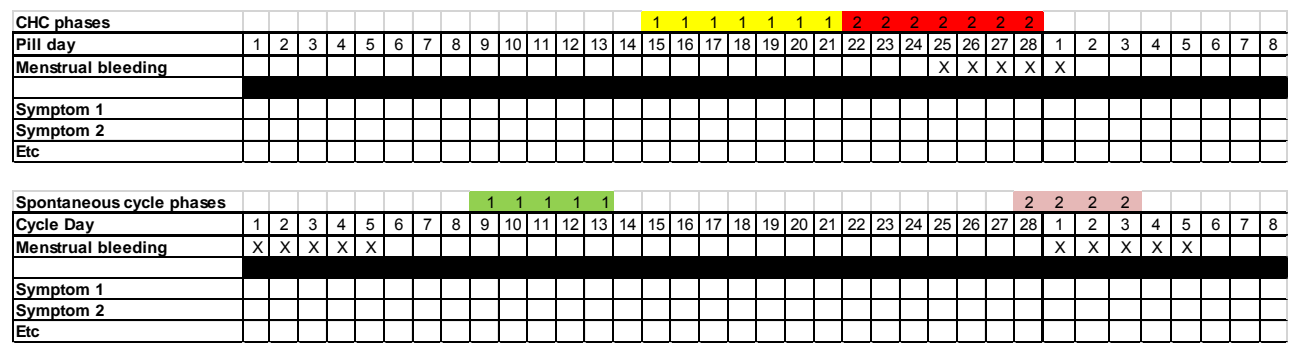

Figure 6. Schematic definition of the phases compared in paper II. For women using $\mathrm{CHC}$ the $\mathrm{CHC}$ phase was defined as pill-day 15-21 (late/high ethinylestradiol/progestogen phase)(yellow) and the non-CHC phase as pill-day 22-28 (no ethinylestradiol/progestogen phase)(red). For women with spontaneous menstrual cycles phase 1 was defined as day 20 to 16 before start of bleeding (high estrogen/low progesterone state)(green) and phase 2 as the day before start of bleeding to the third day of bleeding (low estrogen/progestrone state)(purple) 


\section{Are exposures to high estrogen concentrations for longer periods such as $\mathrm{CHC}$-use and pregnancies before the onset of MS related to age at onset of the disease? (Paper III)}

Study subjects

A questionnaire was sent to all 1009 women 45 years old or younger in the Swedish MS Register (SMS register) with diagnosed MS and living in one of five counties of Sweden. All women had at the time of inclusion in the SMS register given their informed consent to participate in research studies. After one reminder, 837 (83\%) women returned the questionnaire. Of these, 770 women had complete data in the SMS register and were included in the statistical analyses.

\section{Questionnaire}

The questionnaire used in paper III (supplement 4) comprised questions on OC-use, pregnancies, childbirth, breast-feeding, medication as well as age at first MS-symptoms and age at MSdiagnosis. When suitable we used categorized answering options, e.g. duration of COC use. The questionnaires were coded, which enabled us to send a reminder to those women who had not answered after four weeks. After the codes had been eliminated from the questionnaires, data were optically scanned. From the SMS register we collected data regarding age at MS onset according to the woman's neurologist for the women who had returned the questionnaire. 


\section{Do women with MS using CHC have fluctuations of peripheral blood concentrations of specific cytokines, chemokines and transcription factors related to different $T$ cell subsets in relation to high and low estrogen/progestogen phases? (Paper IV)}

\section{Study Subjects}

Women with a proven diagnosis of MS according to the revised McDonald criteria (29), 18 to 40 years old, who were patients at the Departments of Neurology at the University Hospital of Linköping and the Karolinska University Hospital of Stockholm, both in Sweden, were asked to participate. Exclusion criteria were: Expanded Disability Status Scale (EDSS)(84) > 6.5, exacerbation of MS during the last 3 months, ongoing or planned pregnancy, other hormonal contraception than $\mathrm{CHC}$, other inflammatory diseases or other diseases that affects the central nervous system (CNS), anti-depressive medication, mental or language difficulties. Four women using $\mathrm{CHC}$ and four women without hormonal contraception, but with regular menstrual cycles, were included in Linköping and eight women using $\mathrm{CHC}$ and 14 without hormonal contraception were included in Stockholm (Figure 7). MS patients were allowed to use immunomodulatory medication during the study period as long as it was kept constant during a period of three months, including the studied cycle. If a patient had an exacerbation of MS or had to use corticosteroids or antibiotics during the study period she should be excluded, something that did not occur during the study. Fifteen healthy women using $\mathrm{CHC}$ and 15 healthy women without hormonal contraception and with regular menstrual cycles, all 18-45 years old, were included as controls. These women were recruited among students at Linköping University and employees at Linköping University Hospital, Sweden (Figure 7). The inclusion criteria for the controls were the same as for the women with MS except for the MS related criteria. 


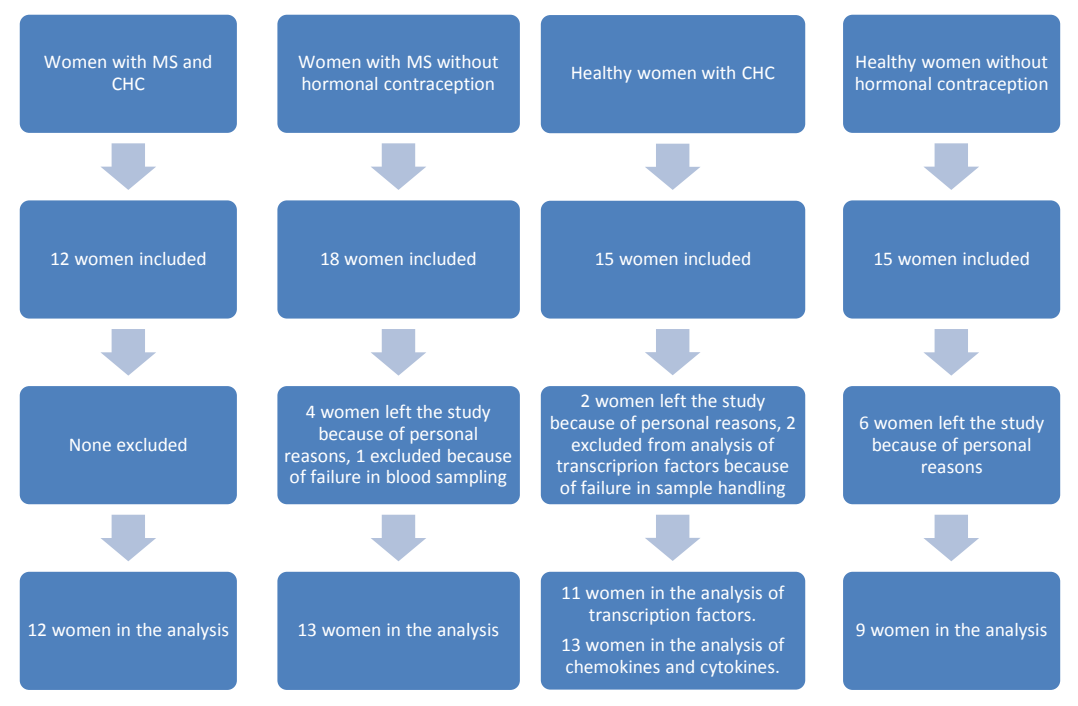

Figure 7. Flow chart of inclusion and exclusion of the women in paper IV.

\section{Blood sampling}

Blood sampling was performed on cycle day 20 or 21 (longest possible high estrogen/progestogen exposure) and day 27 or 28 (longest possible low estrogen/progestogen exposure) for women using $\mathrm{CHC}$ and on cycle day 5, 6, or 7 (longest possible low estrogen/progesterone exposure) and 26, 27, or 28 (longest possible high estrogen/progesterone exposure) for women without hormonal contraception and spontaneous regular menstrual cycles. Cycle day 1 was set to be the first pill-day for the $\mathrm{CHC}$ users and the first day of bleeding for the women without hormonal contraception. At each blood sampling, $6 \mathrm{ml}$ of blood was collected in an EDTA plasma tube. $2.5 \mathrm{ml}$ of blood was also collected using the PAXgene system (PreAnalytix, $\mathrm{GmbH}$, Hombrechtikon, Switzerland). Plasma tubes were centrifuged within 1 hour and $0.5 \mathrm{~mL}$ aliquots of plasma were frozen in $70^{\circ} \mathrm{C}$ until analysis. The PAXgene tubes were frozen in $-70^{\circ} \mathrm{C}$ until analysis. From the women who were not using $\mathrm{CHC}$ we also collected blood samples for $17 \beta$-estradiol and progesterone at each blood sampling. Concentrations of $17 \beta$-estradiol and progesterone were analyzed 
with routine methods at the certified Departments of Clinical Chemistry of the University Hospital, Linköping, Sweden and Karolinska University Hospital, Solna, Sweden.

Multiplex Bead Assay for analyses of cytokines and chemokines

Multiplex Bead Technology (MILLIPLEX ${ }^{\circledR}$ MAP Kit, Human Cytokine/Chemokine Magnetic Bead Panels Cat. \#: HCYTOMAG-60K-11, HCYP2MAG-62K-02 and HCYP3MAG-63K-03) was used to measure cytokines and chemokines in the plasma samples according to the manufacturer's description. Analysed cytokines and chemokines with lowest detection limits and intra- and inter-assay variance according to the manufacturer are shown in table 5 and 6. The samples were analysed on a Luminex ${ }^{\circledR} 200^{\mathrm{TM}}$ instrument (Invitrogen, Merelbeke, Belgium), and the data were collected using the xPONENT 3.1 ${ }^{\mathrm{TM}}$ (Luminex Corporation, Austin, TX, USA) and analyzed using the MasterPlex2010 2.0 (MiraiBio Group, Hitachi Solutions America, Ltd., South San Francisco, CA, USA).

Table 5. Cytokines, Chemokines, and Transcription factors analyzed in paper IV and which T cell subset they represent.

\begin{tabular}{l|ccc|}
\multicolumn{1}{l}{} & $\begin{array}{c}\text { Transcription } \\
\text { factor }\end{array}$ & Cytokines & Chemokines \\
$\begin{array}{l}\text { Inflammation } \\
\text { Inti- } \\
\text { Th1 }\end{array}$ & IL-6, GM-CSF & CXCL8 \\
Th2 & TBX21 & IFN-1RA, M-CSF & \\
Th17 & GATA3 & IL-13 & CCL17, CCL22 \\
T reg & RORC & IL-17A & CXCL1, CXCL8, \\
B cells & FoxP3 & IL-10 & \\
& & & CXCL13
\end{tabular}


Table 6. Cytokines and Chemokines analyzed in paper IV and their lowest detection limit and intraand inter-assay variance according to the manufacturer. $\mathrm{CV}=$ coefficient of variance

\begin{tabular}{|cccc|} 
Cytokine/Chemokine & $\begin{array}{c}\text { Lowest Detection Limit } \\
(\mathbf{p g} / \mathbf{m l})\end{array}$ & $\begin{array}{c}\text { Intra-assay } \\
\text { variance (CV\%) }\end{array}$ & $\begin{array}{c}\text { Inter-assay } \\
\text { variance (CV\%) }\end{array}$ \\
\hline GM-CSF & 1.6 & 3.1 & 10.1 \\
\hline IL-13 & 1.6 & 2.2 & 9.2 \\
IL-17A & 0.8 & 2.2 & 7.9 \\
\hline IL-1RA & 1.6 & 2.1 & 7.2 \\
\hline CXCL10 & 8.0 & 2.6 & 15.3 \\
\hline IL-6 & 0.8 & 2.0 & 18.3 \\
\hline IFN- $y$ & 0.8 & 1.6 & 12.0 \\
\hline IL-10 & 1.6 & 1.6 & 16.8 \\
\hline CXCL8 & 0.8 & 1.9 & 3.5 \\
\hline CXCL1 & 8.0 & 2.1 & 9.2 \\
\hline CCL22 & 8.0 & 1.6 & 7.2 \\
\hline CXCL13 & 2.0 & 4.8 & 6.2 \\
\hline CCL17 & 0.5 & 5.6 & 9.8 \\
\hline CXCL11 & 3.9 & 2.7 & 14.9 \\
\hline CCL20 & 4.9 & 2.1 & 11.6 \\
\hline M-CSF & 48 & 9.1 & 24.4 \\
\hline
\end{tabular}

Extraction of $m R N A$, conversion to $C D N A(R T-P C R)$ and $q P C R$

Total RNA was extracted from whole blood using the PAXgene system according to the manufacturer's instructions and quantity and quality was assessed post-extraction using spectrophotometry (NanoDrop Technologies, Inc., Wilmington, DE, USA). Total RNA was diluted to a fixed concentration before converted into cDNA using the High Capacity cDNA Synthesis Kit (Applied Biosystems, Foster City, CA, USA). The cDNA synthesis was carried out on an Arktik $^{\mathrm{TM}}$ Thermal Cycler (Thermo Fisher Scientific, Waltham, MA, USA). mRNA expression was quantified using the Applied Biosystems 7500 Fast Real-Time PCR System (Applied Biosystems, Foster City, CA, USA). cDNA amplification was performed using TaqMan Universal PCR Master Mix, no AmpErase UNG (Applied Biosystems) in a reaction volume of $20 \mu \mathrm{l}(1 \mu \mathrm{lcDNA})$ for 40 cycles of $3 \mathrm{~s}$ at $95^{\circ} \mathrm{C}$ and $30 \mathrm{~s}$ at $60^{\circ} \mathrm{C}$. All samples were analyzed in duplicate. For quantification of cDNA a five-point serially four-fold diluted standard curve was developed from peripheral blood mononuclear cell cultures stimulated with phytohaemagglutinin. The mRNA expression of the T cell transcription factors was 
standardized to the $T$ cell-specific reference gene $C D 3 E$, and results are expressed as ratios. $C D 3 E$ was used as a reference gene since the ratio of $C D 3 E$ to the general reference gene $18 S$ changed with high/low estrogen/progestogen phases. Expression of CD3E has been shown to be stable at physiological stimulations and in vivo situations and normalizes the expression relative to the $\mathrm{T}$ cell content in the sample (Edström et al, data submitted). TaqMan Gene Expression Assay (Applied Biosystems) was used for analyzing TBX21 (Hs00203436_m1) and RORC (Hs01076112_m1) expression while previously optimized inhouse primers and probes (purchased from Eurogentec, Seraing, Belgium) were used for analyzing 18S, FOXP3 and GATA3 expression (85) and CD3E (Edström, personal communication). An acceptable level of variation among duplicates was set to a coefficient of variance $<15 \%$. The intra-assay variance was $4.9 \%$ for $18 S, 4.9 \%$ for CD3E, $5.6 \%$ for FOXP3, $4.8 \%$ for GATA3, $4.7 \%$ for RORC and $5.7 \%$ for TBX21.

\section{STATISTICS}

Data were analyzed using SPSS versions 16.0 -21.0. Friedman's Test and Wilcoxon's signed rank test were used to analyze differences in mean symptom scores between the different phases of the menstrual cycle and $\mathrm{CHC}$ cycle as described above since the data did not show a normal distribution (Papers I and II). We did also perform factor analyses to assess the factor structure in the data sets and create subscales using this. In paper III we used Pearson correlation and General Linear Models including ANOVA/ANCOVA. In paper IV the concentrations of cytokines, chemokines and transcription factors were analyzed in each of the four groups of women comparing high and low estrogen/progestogen phase samples using Wilcoxons' signed rank test for cytokines and chemokines and paired t-test for transcription factors depending on normal distribution or not. Transcription factors were analyzed as ratios to $C D 3 E$ for TBX21, GATA3, RORC and FOXP3. Between-groups comparisons were done comparing high estrogen/progestogen phase samples using Kruskall-Wallis test for cytokines/chemokines and ANOVA for PCR-data. 


\section{ETHICS}

All studies were approved by the Regional Ethical Committees in Linköping. Paper II was approved by the Regional Ethical Committee in Umeå. Paper II and III were approved by the Ethical Board of the Swedish MS register. All women participating in the studies gave their informed consent.

\section{RESULTS AND DISCUSSION}

Do women with MS who do not use hormonal contraception have variations in symptom experience in correlation to the menstrual cycle? (Paper I)

Do women with MS who use CHC experience more symptoms during the "pill-free" week, i.e. during the low-estrogen/progestogen phase? (Paper II)

The sixteen women who did not use hormonal contraception had a mean symptom score for stiffness that was lower during the low estrogen/progesterone phase 3 compared with the other two phases of the cycle $(p=.036)$ whereas the mean scores for the other symptoms did not vary significantly between the three phases (Table 8). A factor analysis using orthogonal rotation was used to assess the factor structure in the data set. The factor analysis indicated that two factors accounted for about $50 \%$ of the variance. Using this analysis, two subscales were created. Subscale 1 consisted of weakness, urinary symptoms, bowel symptoms, walking impairment and coordination impairment and subscale 2 included double sight and vertigo. The variables included in each subscale had a factor loading higher than 0.6 on the same factor. There were no significant differences between the different phases of the menstrual cycle for subscale $1(p=.571)$ or subscale $2(p=.102)$ in a renewed Friedman's test.

For the seven women who had used CHC, the three symptoms weakness, numbness and tiredness showed higher mean symptom scores during the pill-free phase than during the CHC-phase. A similar trend was noted for most symptoms (Table 9). 
These findings generated the hypothesis that experience of MS symptoms varies with high and low estrogen/progestogen states in women using $\mathrm{CHC}$ so our next task was to test this hypothesis in a larger sample of women (Paper II). Twenty two women with MS using CHC, seven women with MS without hormonal contraception, 10 healthy women using $\mathrm{CHC}$ and four healthy women without hormonal contraception filled out the modified symptom diary. The women with MS are described in Table 7.

Table 7. Number, age and EDSS at last visit before inclusion in the study for the women with MS included in the statistical analyses of Paper II.

\begin{tabular}{l|cc|} 
& CHC & Non-CHC \\
\hline Number & 22 & 7 \\
Age Median (Range) & $34(24-44)$ & $33.5(29-39)$ \\
EDSS Median (Range) & $1.75(0-5)$ & $2.5(1-2.5)$ \\
\hline
\end{tabular}

The results showed that the women using $\mathrm{CHC}$ did experience four of the symptoms significantly worse during the pill-free phase (Table 9). A factor analysis using orthogonal rotation was used to assess the factor structure in the data set. The factor analysis indicated that three factors accounted for $80 \%$ of the variance. Using this analysis, three subscales were created. Subscale 1 consisted of vertigo, weakness, walking impairment, stiffness and numbness, subscale 2 included visual impairment and bowel symptoms and subscale 3 included double sight and urinary symptoms. The variables included in each subscale had a factor loading higher than 0.6 on the same factor. Hypothesis testing using Wilcoxon's signed rank test showed significantly higher total symptom scores in the non-CHC phase compared with the $\mathrm{CHC}$ phase for subscale $1(p=.01)$ and subscale $3(p=.028)$ but not for subscale $2(p=.553)$

Women with MS without hormonal contraception did not have statistically significant differences in symptom scores between high and low estrogen/progesterone phases of the 
menstrual cycle (Table 8) and women without MS did not experience any symptoms according to the diaries.

Table 8. Symptom scores for the sixteen women with MS not using CHC in paper I and the 7 women with MS not using $\mathrm{CHC}$ in paper II. Scores are shown as mean daily score in the three phases over three menstrual cycles. In paper I phase 1 was defined as that extending from cycle day 15 to day 13 before the start of the menstrual bleeding (high estrogen phase), phase 2 as that starting on cycle day 9 and ending on day 5 before the start of menstrual bleeding (high estrogen and progesterone phase), and phase 3 as that from the day before the start of menstrual bleeding until the third day of menstrual bleeding (low estrogen and progesterone phase). Hypothesis testing was done with Friedman's test. For paper II phase 1 was defined as day 20 to 16 before start of bleeding (high estrogen/low progesterone state) and phase 2 as the day before start of bleeding to the third day of bleeding (low estrogen/progesterone state) over three cycles. The hypothesis was tested using Wilcoxon's signed rank test.

Paper I $(n=16) \quad$ Paper II $(n=7)$

\begin{tabular}{|c|c|c|c|c|c|c|c|}
\hline & Phase 1 & Phase 2 & Phase 3 & p & Phase 1 & Phase 2 & $\mathbf{p}$ \\
\hline Visual impairment & 0.38 & 0.39 & 0.42 & 0.497 & 1.54 & 2.07 & .109 \\
\hline Double vision & 0.12 & 0.09 & 0.09 & 0.223 & 1.01 & 1.27 & .317 \\
\hline Vertigo & 0.27 & 0.32 & 0.43 & 0.102 & 1.89 & 2.09 & .593 \\
\hline Weakness & 0.78 & 0.83 & 0.94 & 0.294 & 1.72 & 1.63 & .109 \\
\hline Urinary symptoms & 0.57 & 0.59 & 0.57 & 0.827 & 1.67 & 1.48 & .180 \\
\hline Bowel symptoms & 0.31 & 0.33 & 0.27 & 0.779 & 1.26 & 1.18 & .318 \\
\hline Walking impairment & 1.00 & 1.06 & 0.95 & 0.433 & 1.52 & 1.55 & .593 \\
\hline Stiffness & 0.82 & 0.94 & 0.76 & 0.036 & 1.81 & 2.08 & .273 \\
\hline $\begin{array}{l}\text { Coordination } \\
\text { impairment }\end{array}$ & 0.54 & 0.55 & 0.56 & 0.801 & 1.29 & 1.33 & .317 \\
\hline Numbness & 0.73 & 0.77 & 0.85 & 0.614 & 1.73 & 2.06 & .109 \\
\hline Tiredness & 1.17 & 1.28 & 1.36 & 0.063 & & & \\
\hline Mood symptoms & 0.31 & 0.40 & 0.47 & 0.728 & & & \\
\hline Behavioural symptoms & 0.13 & 0.13 & 0.13 & 0.368 & & & \\
\hline
\end{tabular}


Table 9. Symptom scores for the seven women with MS using CHC (Paper I) and the 22 women with MS using $\mathrm{CHC}$ (Paper II). Scores are shown as mean score of 8 days during $\mathrm{CHC}$ phase and 4 days during non- $\mathrm{CHC}$ phase and over three 28-day cycles for paper I and as mean score of the days 15-21 (CHC phase) and days 22-28 (non$\mathrm{CHC}$ phase) and over three 28-day cycles for paper II. Hypothesis testing using Wilcoxon's signed rank test.

Paper I ( $n=7)$

Paper II ( $n=22)$

\begin{tabular}{|c|c|c|c|c|c|c|}
\hline & CHC phase & Non-CHC phase & p & CHC phase & Non-CHC phase & $\mathbf{p}$ \\
\hline Visual impairment & 0.17 & 0.34 & 0.109 & 1.28 & 1.30 & 1.000 \\
\hline Double vision & 0.02 & 0.14 & 0.317 & 1.00 & 1.02 & .180 \\
\hline Vertigo & 0.29 & 0.64 & 0.273 & 1.41 & 1.84 & .008 \\
\hline Weakness & 0.53 & 1.12 & 0.043 & 1.77 & 2.00 & .046 \\
\hline Urinary symptoms & 0.15 & 0.27 & 0.655 & 1.30 & 1.40 & .043 \\
\hline Bowel symptoms & 0.12 & 0.35 & 0.109 & 1.20 & 1.21 & .799 \\
\hline Walking impairment & 0.46 & 0.93 & 0.068 & 1.85 & 1.91 & .753 \\
\hline Stiffness & 0.53 & 1.04 & 0.068 & 1.93 & 2.46 & .010 \\
\hline $\begin{array}{l}\text { Coordination } \\
\text { impairment }\end{array}$ & 0.26 & 0.40 & 0.180 & 1.27 & 1.55 & .091 \\
\hline Numbness & 0.63 & 1.33 & 0.018 & 1.94 & 2.46 & .050 \\
\hline Tiredness & 0.88 & 1.51 & 0.028 & & & \\
\hline Mood symptoms & 0.40 & 0.49 & 0.109 & & & \\
\hline Behavioural symptoms & 0.07 & 0.06 & 0.317 & & & \\
\hline
\end{tabular}

When we started planning these studies, there were only retrospective studies published on female MS patients' experiences of MS symptoms in relation to the menstrual cycle. $(51,52)$ These studies showed that some women with MS reported worsening of symptoms just before or at the beginning of menstruation, at least if they had the RR type of MS, and that women using oral contraceptives (type not specified) experienced less worsening of symptoms than women without oral contraceptives. One study showed that the premenstrual period may be a period when exacerbations of MS are more easily triggered. (53) Based on this sparse knowledge we planned to prospectively study MS symptom experience in women in relation to high and low estrogen phases during the menstrual cycle. The first symptom diary (paper I) was designed together with an experienced neurologist and MS specialist at the Department of Neurology at the University Hospital of Linköping. 
Our results are in contrast to results from the earlier retrospective studies of symptom experience in relation to the menstrual cycle. $(51,52)$ The women with MS without hormonal contraception did not experience any significant worsening of symptoms during the menstrual, low estrogenic/progestogenic, phase of the cycle. The analysis of the subscales based on the factor analysis strengthened these results. On the other hand, despite the low number of patients studied, the women with MS using CHC experienced their symptoms significantly worse during the pill-free phase of the $\mathrm{CHC}$ cycle. One explanation of this difference between the two groups of women could be that the women who use $\mathrm{CHC}$ go from a state with high serum concentration of the highly potent estrogen $\mathrm{EE}$ to a state of very low levels of estrogens, which may lead to worse symptoms while the cyclic variation in estrogen concentration in women without hormonal contraception is too small to produce the same effects. Our results (Paper II) showed that the women using $\mathrm{CHC}$ experienced four of the symptoms significantly worse during the pill-free phase (Table 9). The factor analysis and the subsequent hypothesis testing of the subscales did also show higher symptom experience scores during the low estrogen/progestogen phase. Women with MS with regular menstrual cycles and without hormonal contraception did not have significant differences in symptom scores between high and low estrogen/progesterone phases of the menstrual cycle (Table 8) which is in line with the results in paper I. The women without MS did not experience any of the MS-symptoms according to the diaries.

Worsening of MS-symptoms in the luteal phase of the menstrual cycle has been suggested to be caused by the increased body temperature during the luteal phase since a rise in body temperature may elicit worsening of MS-symptoms(86) The luteal phase is a highprogesterone, high-estrogen part of the menstrual cycle and in the present study we found that symptom scores rose when the women shifted from an extremely high to low estrogen level. Since estrogens, and especially EE, seem to cause beneficial immunological effects on MS and the mouse model Experimental Allergic Encephalitis (EAE), the lower symptom scores during the $\mathrm{EE}$ phase of $\mathrm{CHC}$ are suggested to be related to immunological effects of EE. $(37,43,80,81)$ 
Are exposures to high estrogen concentrations for longer periods such as CHC-use and pregnancies before the onset of MS related to age at onset of the disease? (Paper III)

Table 10 shows the base data of the 770 women included in the statistical analysis. There was a significant difference in mean age at onset for the first MS symptoms between women who had and had not been using $\mathrm{CHC}$ respectively ( 26 vs 19 years, $\mathrm{p}<.001$ ). The total duration of $\mathrm{CHC}$ use before the onset of MS was categorized in six categories. The age at onset was higher the longer the women had been using $\mathrm{CHC}$ before the onset of MS (Table 11). The number of children born before the first MS symptom was correlated with age at MS onset (Figure 8). In a full factorial General Linear Model analysis, including age at start of $\mathrm{CHC}$ use, both duration of $\mathrm{CHC}$ use and number of children born before the first MS symptom had independent statistically significant effects on age at onset of MS (table 12).

Table 10. Base data of the 770 women included in the statistical analysis of paper III.

\begin{tabular}{|l|c|}
\hline \multicolumn{1}{|l|}{ Age Median yrs (Range) } & $38(16-46)$ \\
\hline \multicolumn{1}{|l|}{ MS Course } & \\
\hline \multicolumn{1}{|c|}{ SP } & 649 \\
\hline \multicolumn{1}{|c|}{ Others } & 97 \\
\hline \multicolumn{1}{|c|}{ PP } & 12 \\
\hline EDSS Median (Range) & 12 \\
\hline CHC ever user Nr (\%) & $2.0(0-9.0)$ \\
\hline Smoker Nr (\%) & $609(79 \%)$ \\
\hline MS Duration Median yrs (Range) & $140(18 \%)$ \\
\hline Age at first symptom Median yrs (Range) & $9(1-38)$ \\
\hline Age at MS diagnosis Median yrs (Range) & $25(4-45)$ \\
\hline
\end{tabular}

Table 11. Mean age \pm SD at onset of Multiple Sclerosis (MS) for groups of the women in relation to CHC use before the first MS symptom.

\begin{tabular}{c|ccccccc|}
\multicolumn{2}{c}{} & Less than 1 & $1-3$ & $4-5$ & $6-10$ & More than 10 & \\
year & years & years & years & years & p \\
\hline $\begin{array}{c}\text { Age at MS } \\
\text { onset }\end{array}$ & $19 \pm 5.4$ & $24 \pm 7.3$ & $24 \pm 6.3$ & $25 \pm 5.6$ & $27 \pm 4.4$ & $32 \pm 4.5$ & $<.001$
\end{tabular}




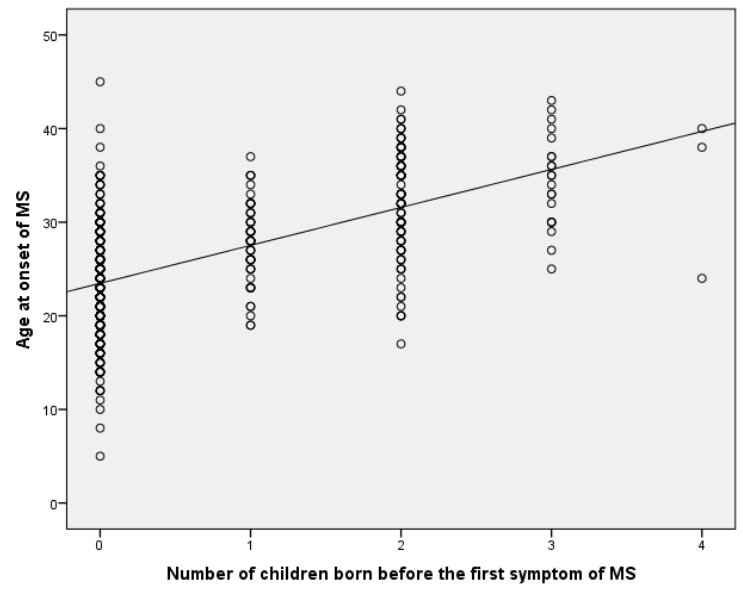

Figure 8. Correlation of Age at onset of MS to number of children born before the first symptom of MS. $R=.576, p<.001$.

We found that use of $\mathrm{CHC}$ before the onset of MS was related to a later onset of the disease. This contradicts the results from two previous cohort studies which did not show any effect of OCs on incidence or risk of developing MS $(58,59)$. In these two studies the term "oral contraceptives" was used without a clear definition of whether this included progestin-only pills or not. A case-control study, where the authors clearly specified that the most frequent OC in the study was COC, had findings in line with our results and showed a $40 \%$ lower incidence of MS among women who had been using OC during the preceding three years compared with those who had not. Recently after our publication, three studies have investigated the long-term effects of oral contraceptives on the course of MS. Sena et al showed a more benign course of the MS for women who had used OC after the onset of MS (62) whereas D'hooghe et al reported a worse disease course for OC users with progressive onset MS but not for RR MS.(63) The recently published study by Gava et al showed that $\mathrm{CHC}$ users had lower disease scores but only if they had prior or current immunomodulatory medication. Non-users of $\mathrm{CHC}$ had higher risk of developing SP MS. In the same study the age at onset of MS was not related to the use of $\mathrm{CHC}$, contradicting our results.(60) Regarding the correlation between term pregnancies and age at onset of MS D'hooghe et al also published a study which showed that childbirth at any time before or after the onset of MS was related to a reduced risk of reaching EDSS 6.(73) 
Based on our findings and on other published data we speculate that use of $\mathrm{CHC}$ and term pregnancies, due to the long periods of high estrogenic exposure, may affect the immunological pathways and delay the onset of MS in women with a predisposition of having the disease. It is important to emphasize that this study does not prove this effect. It could be argued that the later the woman has had her onset of MS, the longer the possible time been during which she could have been exposed to $\mathrm{CHC}$ and pregnancies. This point of view is contradicted, however, by our results concerning the differences in mean age at MS onset between the groups of women. The difference in mean age at MS onset was five years between women who had not used $\mathrm{CHC}$ and women who reported use of $\mathrm{CHC}$ for less than one year (Table 11). Between the "less than one year"-group and the "1-3 years"-group there was no difference in mean age at MS onset. The women who reported 4-5 years of $\mathrm{CHC}$ use had only one year higher mean age at MS onset than the women who reported less than one year of $\mathrm{CHC}$ use. If the duration of $\mathrm{CHC}$ use would be longer the higher the age at MS onset, these differences most probably would have been much larger. The full factorial GLM analysis including age at start of $\mathrm{CHC}$ use showed that both duration of $\mathrm{CHC}$ use and number of children born before the first MS symptom had independent statistical effects on age at onset of MS (Table 12). The studies regarding the effects of $\mathrm{CHC}$ on the incidence, age at onset and disease course of MS show divergent results and the issue therefore needs to be further studied.

Table 12. Statistical effects of use of CHC, Number of children born before first MS symptom and age at $\mathrm{CHC}$ start on age at MS onset in a full factorial General Linear Model

\begin{tabular}{l|cc|}
\multicolumn{1}{l|}{} & $\mathbf{F}$ & $\mathbf{p}$ \\
\hline Corrected Model & 159 & $<.001$ \\
Age at CHC start & 240 & $<.001$ \\
Nr of children & 314 & $<.001$ \\
CHC use & 101 & $<.001$ \\
\hline
\end{tabular}




\section{Do women with MS using CHC have fluctuations of peripheral blood concentrations of specific cytokines, chemokines and transcription factors related to different $T$ cell subsets in relation to high and low estrogen/progestogen phases? (Paper IV)}

In total 60 women were included but 13 dropped out for various reasons leaving 47 women in the statistical analyses (Figure 7, Table 13 and Table 14). All the women with MS had RR MS. All women using $\mathrm{CHC}$ were on a $21 / 7$ days regimen. According to the symptom diaries, eight of the 13 women with MS without hormonal contraception had a median cycle length of 28 days, range 27-29 days, and 4 of the 9 healthy controls had a median cycle length of 26.5 days, range 24-33 days. Serum concentrations of E2 and progesterone for the women who were not using hormonal contraception are shown in Table 13. Comparisons of transcription factors in paired high versus low estrogen/progestogen phases within each group are presented in Figure 8. In healthy controls using CHC, TBX21 and GATA3 expression was higher in the CHC-phase than in the pill-free phase (Figure 9). No other transcription factor was significantly different between high and low estrogen/progestogen phases in any of the four groups.

Table 13. Age and parity of the four groups of women in the study and estradiol and progesterone concentrations of the women without combined hormonal contraception (CHC).

\begin{tabular}{|c|c|c|c|c|c|}
\hline & & $\begin{array}{c}\text { Controls } \\
\text { without CHC } \\
(n=9)\end{array}$ & $\begin{array}{l}\text { Controls with } \\
\text { CHC (n=13) }\end{array}$ & $\begin{array}{l}\text { MS patients } \\
\text { without CHC } \\
\quad(n=13)\end{array}$ & $\begin{array}{c}\text { MS patients } \\
\text { with CHC } \\
\text { (n= 12) }\end{array}$ \\
\hline $\begin{array}{l}\text { Age - Median } \\
\text { (Range) }\end{array}$ & & $27(21-42)$ & 23 (21-29) & 36 (25-39) & $27(22-40)$ \\
\hline $\begin{array}{l}\text { Parity - } \\
\text { Median } \\
\text { (Range) }\end{array}$ & & $0(0-4)$ & $0(0-2)$ & $0(0-2)$ & $0(0-4)$ \\
\hline $\begin{array}{l}\text { Estradiol } \\
\text { (pmol/L) } \\
\text { Mean (SD) }\end{array}$ & $\begin{array}{l}\text { Cycle Day 5-7 } \\
\text { Cycle Day 26-28 }\end{array}$ & $\begin{array}{c}124(39) \\
522(365)\end{array}$ & & $\begin{array}{l}130(121) \\
360(251)\end{array}$ & \\
\hline $\begin{array}{l}\text { Progesterone } \\
\text { (nmol/L) } \\
\text { Mean (SD) }\end{array}$ & $\begin{array}{l}\text { Cycle Day 5-7 } \\
\text { Cycle Day 26-28 }\end{array}$ & $\begin{array}{c}1.9(0.7) \\
25.2(22.0)\end{array}$ & & $\begin{array}{c}1.5(0.8) \\
16.6(13.2)\end{array}$ & \\
\hline
\end{tabular}


Table 14. Duration of MS, Expanded Disability Status Scale (EDSS) and Multiple Sclerosis Severity Score (MSSS) at inclusion and immunomodulatory medication by the MS patients with and without Combined Hormone Contraception (CHC).

\begin{tabular}{|c|c|c|c|}
\hline & & No $\mathrm{CHC}$ & $\mathrm{CHC}$ \\
\hline MS duration, Years Median (Range) & & $3(1-10)$ & $7(2-18)$ \\
\hline EDSS, Median (Range) & & $1.5(0-2.5)$ & $1.25(0-3.5)$ \\
\hline MSSS, Mean (SD) & & $2.37(2.02)$ & $2.32(2.39)$ \\
\hline \multirow[t]{6}{*}{$\begin{array}{l}\text { Immunomodulatory medication, } \\
\text { Number of patients }\end{array}$} & Fingolimod & 0 & 1 \\
\hline & Glatiramer & 0 & 1 \\
\hline & IFN- $\boldsymbol{\beta}$ & 8 & 3 \\
\hline & Natalizumab & 4 & 3 \\
\hline & Rituximab & 0 & 1 \\
\hline & $\begin{array}{l}\text { No } \\
\text { medication }\end{array}$ & 1 & 3 \\
\hline
\end{tabular}

For the between-group comparisons, data on the high estrogen/progestogen phases are shown since these reflect the maximum recorded estrogen/progestogen effects in the different groups (Figure 10). TBX21 expression in high estrogen/progestogen phases differed significantly across the groups with the highest expression levels in healthy controls without CHC. FOXP3 expression in the high estrogen/progestogen phase was significantly higher in MS patients without CHC. Since the frequency of IFN- $\beta$ medication differed between MS patients with and without $\mathrm{CHC}$, data were re-analyzed and after exclusion of all IFN- $\beta$ users there were no significant differences in FOXP3 expression between groups. For GATA3 and $R O R C$ no differences in expression levels were found across groups. 


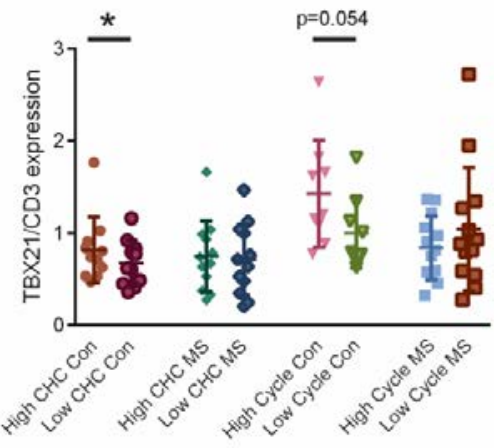

FOXP3

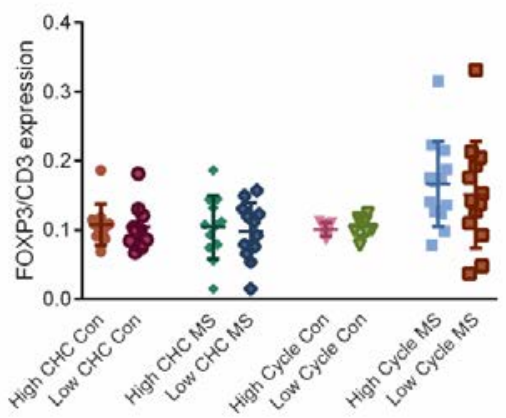

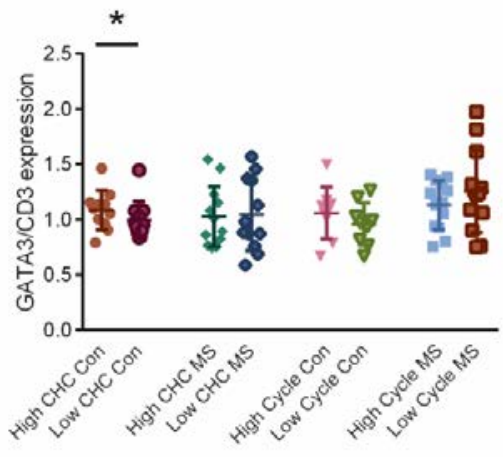

RORC

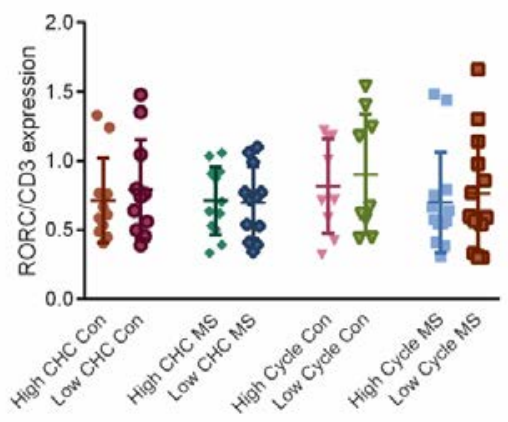

Figure 9. Within group comparisons of transcription factors in High versus Low estrogen/progestogen phases in MS patients (MS) and healthy controls (Con) with combined hormonal contraception (CHC) and with natural menstrual cycle (Cycle).Transcription factor expression is presented as mean and SD relative to $C D 3 E$ expression. Hypothesis testing using paired t-test. * $p<.05$ 


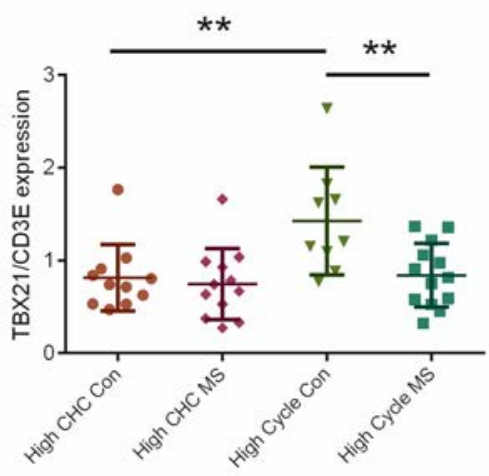

FOXP3

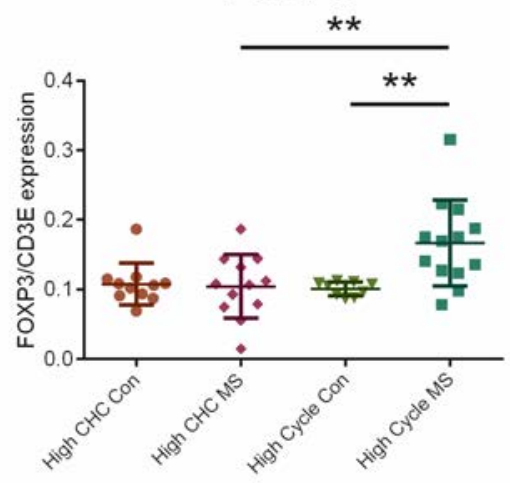

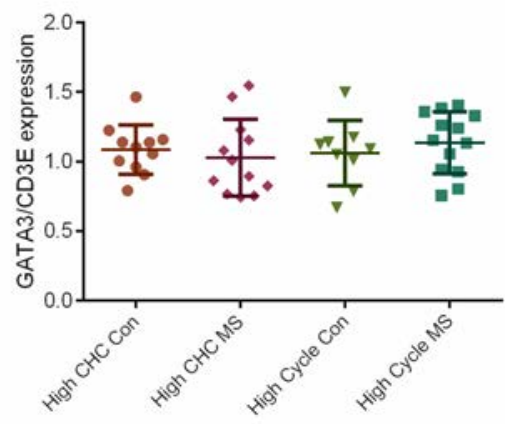

RORC

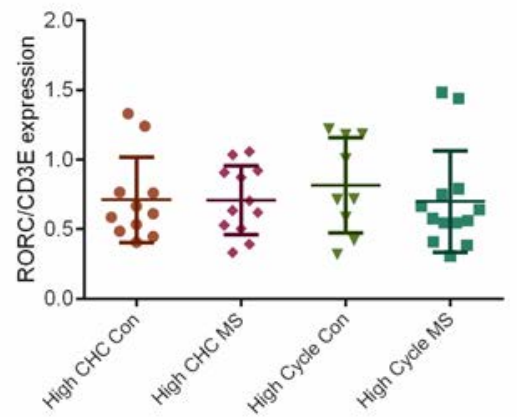

Figure 10. Between group comparisons of TBX21, GATA3, FOXP3 and RORC in high estrogen/progestogen phases in the four study groups of MS patients (MS) and healthy controls (Con) with combined hormonal contraceptives $(\mathrm{CHC})$ and with natural menstrual cycle (Cycle).Transcription factor expression is presented as mean and SD relative to CD3E expression. Hypothesis testing using ANOVA. ${ }^{* *} p<.01$

Comparisons of cytokines and chemokines in high versus low estrogen phases within each group are presented in Table 15. Results of CCL20 and M-CSF are not presented since these analytes were not detectable. In all MS patients and in healthy controls using $\mathrm{CHC}$ the concentrations of CXCL13 were significantly higher in the high estrogen/progestogen phase compared to the low estrogen/progestogen phase (Figure 11). In MS patients using CHC the concentration of IL-13 was higher in the pill-free phase than in the CHC-phase and in MS 
patients without hormonal contraception the concentration of IL-10 was higher in the high estrogen/progesterone phase than in the low estrogen/progesterone phase. No other concentrations of the cytokines or chemokines analyzed were significantly different between high and low estrogen/progestogen phases in any of the four groups (Table 15). Neither were there any differences in the cytokine and chemokine levels of the high estrogen/progestogen phase when comparing the four groups of women (not shown).

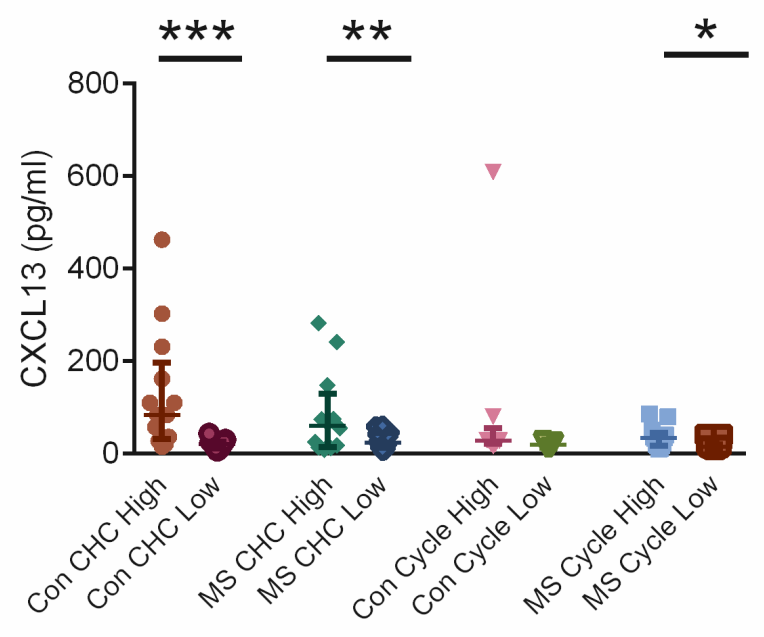

Figure 11. Concentration of CXCL13 in plasma in High versus Low estrogen/progestogen phases in MS patients (MS) and healthy controls (Con) with combined hormonal contraception ( $\mathrm{CHC}$ ) and with natural menstrual cycle (Cycle). Concentrations are presented as median and $25^{\text {th }}$ and $75^{\text {th }}$ percentiles. Hypothesis testing using Wilcoxon's signed rank test. ${ }^{*} p<.05,{ }^{* *} p<.01 .{ }^{* * *} p<.001$ 


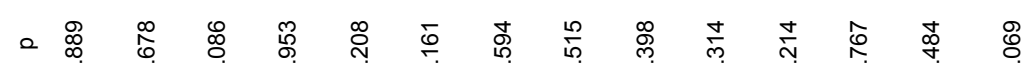
产

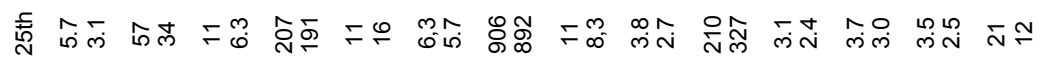

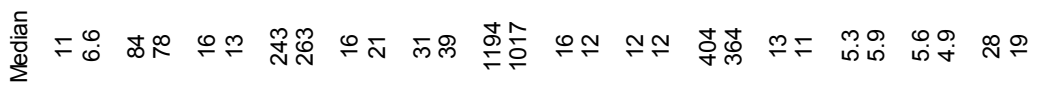
○

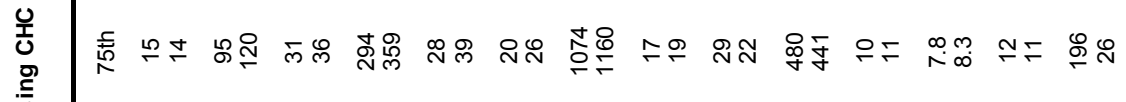

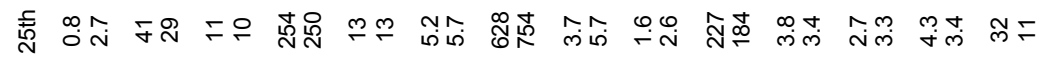
覆

ฮ

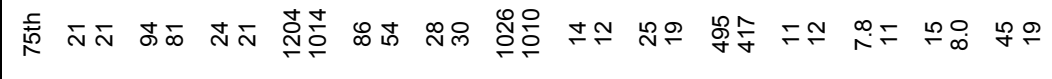

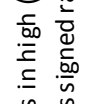

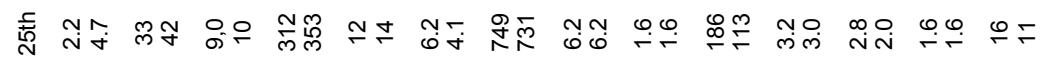

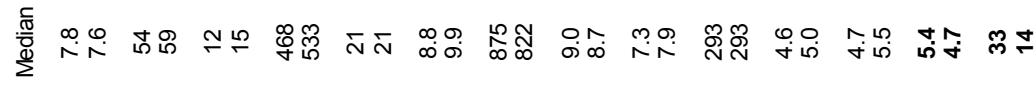

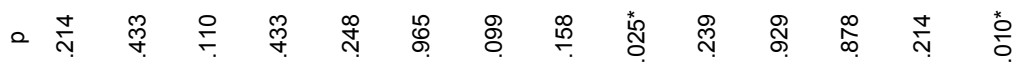
站 点

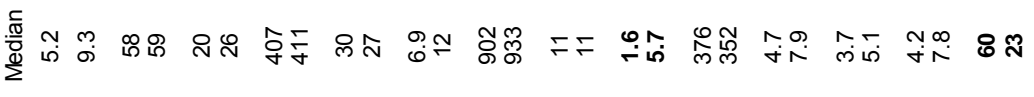


Since TBX21 and GATA3 are specific transcription factors for Th1 and Th2, respectively, our finding of higher expression of both TBX21 and GATA3 in the CHC-phase in the control group using $\mathrm{CHC}$ indicates increased activity of both Th1 and Th2 during the high estrogen/progestogen phase of $\mathrm{CHC}$ users. In line with this finding, higher concentrations of the Th2-associated cytokine IL-4 have been shown during the luteal phase of the menstrual cycle.(54) However, our finding of increased Th1 activity in the high estrogen/progestogen phase of $\mathrm{CHC}$ users is in contrast to earlier studies showing no fluctuations of Th1 activity in relation to high and low estrogen states, at least during normal menstrual cycle. $(54,87)$ Another main finding is the higher CXCL13 concentrations in high estrogen/progestogen phases of both MS patients with and without $\mathrm{CHC}$ and controls with $\mathrm{CHC}$. CXCL13 acts as a chemo-attractant to B cells by binding to its receptor CXCR5 and is involved in homing of lymphocytes in lymphoid organs.(88) CXCL13 is associated with inflammation and neural damage in the CNS in EAE.(89) In MS patients, CXCL13 concentrations in the cerebrospinal fluid (CSF) are related to disease activity and the CSF concentrations decrease after treatment with steroids or the immunomodulatory drug Natalizumab. $(90,91)$ It has been shown that E2 treatment of FoxP3-deficient mice (prone to inflammation), given before induction of EAE, protects against histopathological and clinical signs of disease and leads to decreased expression of TNF, IFN- $\gamma$ and IL-17 in the CNS. However, these inflammatory cytokines showed increased expression in peripheral lymphoid organs along with increased expression of CXCL13 and its receptor CXCR5 in the spleen. Thus, increased immune activation in the periphery, such as our finding of increased transcription factor levels as well as CXCL13 plasma levels, may be associated with sequestration of immune activity in the periphery linked to a decreased inflammation in the CNS. Another possible scenario that can explain increased CXCL13 levels as a marker of beneficial immunological effects in the context of inflammation is that the increased B cell activity is related to increase in regulatory properties of B cells. Indeed, Bodhankar et al showed that the protective effects of E2 are dependent on B cells.(48) Further, immunomodulatory effects of pregnancy have been linked to expansion of regulatory B cells.(92) Thus, it seems warranted to further delineate estrogenic immunomodulatory effects in relation to B cells. In support of this notion, $\mathrm{B}$ cell fluctuations in relation to different phases of the menstrual cycle have been shown in women using CHC.(93) In our study, the differences of CXCL13 between high and low estrogen/progestogen phases were largest in women using $\mathrm{CHC}$, which could reflect a 
stronger effect of EE in comparison to E2 on CXCL13 expression. In contrast to this we found higher IL-10 levels during the high estrogen/progestogen phase only in MS patients without hormonal contraception. IL-10 is secreted by regulatory T cells and in line with our finding increased activity of Tregs was found during high estrogen states in healthy women.(57) Also in MS patients, high estrogen states are associated with more Treg activity.(80) IL-10 expression in blood has also been shown to correlate with high lesion load and Gadolinium enhanced lesions on MRI.(94) In our study, the Treg associated transcription factor FOXP3 showed a higher expression in the high estrogen/progestogen phase of MS patients without hormonal contraception in comparison to all the three other groups although this finding was explained by the higher frequency of IFN- $\beta$ medication in that group. To summarize, the findings in paper IV are in line with a general activation of peripheral blood T cells and B cells during high estrogen/progestogen phases. Transcription factors specific for both Th1 (TBX21) and Th2 (GATA3) subsets of T cells as well as the B cell activator CXCL13 showed higher levels during high estrogen/progestogen states. These findings may indicate that the beneficial effects of estrogens on immune processes involved in MS may be due, at least in part, to peripheral sequestration of T cells and involvement of regulatory B cells. The differences between high- and low estrogen/progestogen phases were most obvious in women using $\mathrm{CHC}$ indicating that $\mathrm{EE}$ is more potent than $\mathrm{E} 2$ in inducing immune changes in both MS patients and healthy women.

\section{COMMENTS ON METHODOLODY}

\section{Study subjects and sample sizes}

MS is a disease with a prevalence of only about 2 in 1000 in Sweden.(5) One of the main obstacles during the studies was to find and recruit women with MS who were using CHC. The prevalence of $\mathrm{CHC}$ use among the 240 responders in the inclusion process of study II (Paper II) was only 7.1\% whereas in the general population of corresponding age it is almost double. (95) The low frequency of $\mathrm{CHC}$ use may thus be one of the reasons for the slow inclusion rate but we did not perform a drop-out analysis of those 281 women who did not answer the invitation to participate so the frequency of $\mathrm{CHC}$ use in that group remains 
unknown. It is plausible that women with severe chronic diseases, including MS, are advised not to use hormonal contraceptive methods since the effects of sex steroids in a large number of diseases are to a large extent unknown. Many women with MS already participate in clinical trials which also can be an explanation of the low recruitment in this study. The low number of women who were able to participate in the studies constitutes a risk of selection bias. A low number of participants also reduces the statistical power and consequently increases the risk of a type two error. In papers I, II and IV, however, the main comparisons are made between samples from the same patient in a pairwise way which makes the results more reliable despite the low number of patients. In the only study where the main comparisons are made between groups (III), the response rate was high, $83 \%$ and consequently also the number of patients included in the statistical analyses.

The majority of the MS patients in the studies were using immunomodulatory therapy, which may have affected the results. Since these therapies have indicated possibly dramatic improvements in MS therapy, it would be unethical to withdraw the immunomodulatory treatment when performing studies on MS-patients like our patients. The use of these drugs was kept unchanged during the study periods. Decreased symptom experience and lower concentrations of disease activity-related cytokines and chemokines is possible during use of immunomodulatory treatment, as well as a reduced responsiveness to other immunomodulators such as estrogens which may have affected the results in study IV (paper IV).

\section{Symptom diary}

When planning the study which paper I is based on, the only previous studies of experience of MS symptoms published were two retrospective studies. The symptom diary was designed in cooperation with an experienced neurologist and MS specialist to prospectively measure experience of MS symptoms. The pilot study (Paper I) generated the hypothesis that symptom experience varies between high and low estrogen/progestogen phases in women using $\mathrm{CHC}$ but does not vary in women with natural menstrual cycles and we then planned to test this hypothesis in a larger sample. During this planning process we decided 
to exclude three symptoms that could be mistaken as general premenstrual/menstrual symptoms. We then made the decision to modify and use a validated instrument for measuring PMS/PMDD symptoms in relation to the menstrual cycle, called Cyclicity Diagnoser (CD). It is, however, important to address the fact that the modified form of the diary used in paper II is not validated. In both paper I and II there may of course be a risk that the participants have scored their symptoms higher during a specific period of the cycles since they knew that the study aimed to investigate variations in symptom experience in relation to the cycle. The participants did not know, however, in which part of the cycle we expected the symptom experience to be stronger and they may even have thought that the symptoms were expected to be worse during the $\mathrm{CHC}$ period. The number of participants in these two studies is a limitation but the prospective design is a strength since it eliminates the risk of recall bias.

\section{Questionnaire}

The questionnaire used (paper III) was designed by the authors. The questionnaire was initially tested on a few MS patients at the Department of Neurology of the University Hospital in Linköping. The written and oral answers were compared. Some of the data obtained from the questionnaire were also noted in the SMS register and the data on age at onset showed a high correlation between the two sources of data $(r=0.879, p<.001)$. This high correlation between the data from the questionnaire and the data from the SMS register indicates a high reliability of the questionnaire data.

In a questionnaire where the participants are asked about things that happened many years ago, such as duration of use of a specific medication, there is always a risk of incorrect answers with such relatively high frequency that the results are affected this recall bias. In the present study this means that it could be hard for a woman to remember the exact age when she started using $\mathrm{CHC}$ or the exact duration of the usage, especially, if she has been using $\mathrm{CHC}$ during separate periods of her life. In order to compensate for this, we used categorized periods of time, instead of the estimated exact duration of CHC-use. In any case, this may have skewed the results but not in any specific direction. Moreover, the 
retrospective design would have made answers to questions on type of CHC previously used too uncertain. Therefore, we can only draw conclusions on $\mathrm{CHC}$ in general and not on any specific combination of $\mathrm{EE} /$ progestogen. The data regarding the number of children a woman has given birth to and when the children were born are most probably highly reliable.

Immunological assays

We decided to use blood samples to analyze the concentrations of cytokines and chemokines in plasma and the PAXgene system to extract mRNA for conversion to CDNA to be measured using quantitative RT-PCR. It can be questioned how well the expression of cytokines, chemokines and transcription factors in peripheral blood reflects MS disease activity. There are studies showing that peripheral concentrations of many cytokines and chemokines are related to disease activity as measured by MRI or as measured by CSF sampling but the clinical relevance of these correlations is not clear. $(94,96-98)$ Ideally both CSF- and peripheral blood samples should have been included in the analyses but that design did not seem realistic as the recruitment of patients for the studies was not easy and would have been even more difficult if the method had included CSF sampling.

There may be a large intra-individual variation in the length of the menstrual cycle. Consequently, the timing of the blood sampling may be difficult. Ideally one blood sample should have been drawn every day during the cycle but for practical reasons that was not possible. According to the study protocol for the women using $\mathrm{CHC}$ we drew the blood samples one of the two last days of active hormone medication and one of the two last days of the pill-free period to achieve the longest possible high and low estrogen/progestogen exposure. We do not know for sure that the $\mathrm{CHC}$ users have taken their $\mathrm{CHC}$ every day. It is well known that users of $\mathrm{CHC}$ frequently forget to take their pills every day. (99) In the diaries, however, the participants were asked to tick a box if they did forget to take a tablet and we could also see from the regular bleeding pattern registered in the diaries that the women seem to have taken their $\mathrm{CHC}$ as prescribed. 
For the women who were not using hormonal contraception one sample in a low estradiol and low progesterone phase, cycle day 5-7 and one sample in a high estrogen and high progesterone phase, cycle day 26-28 was obtained. The expected variations in sex steroid concentrations between the different phases of the cycle were found and are shown in table 13.

The $C D 3 E / 18 S$ ratio was significantly lower in the high estrogen/progestogen phase than in the low estrogen/progestogen phase in MS patients using $\mathrm{CHC}(\mathrm{p}=.012)$ and in healthy controls using $\mathrm{CHC}(\mathrm{p}=.015) . \mathrm{CD} 3 E$ is a part of the $\mathrm{CD} 3 / \mathrm{T}$ cell receptor complex and is expressed only by $T$ cells. Since $C D 3 E$ expression is stable at physiological stimulations and at in vivo conditions and since it reflects the T cell content in mixed cellular compartments such as blood, it serves as a reliable cell-specific reference gene (Edström et al, data submitted). Indeed, previous studies indicated estrogenic effect on T cell number during normal menstrual cycles (87) and during $\mathrm{CHC}$ cycles (93). Therefore, our approach of using CD3E instead of $18 S$ as a reference gene seems justified.

It is important to address the fact that we analyzed 16 cytokines and chemokines, four transcription factors, of which only a few showed statistically significant fluctuations in relation to high and low estrogen phases or between the groups of women included in the study. The lack of more significant results could of course be a consequence of a low number of study subjects, i.e. low statistical power of the study. In comparison to other studies on immunological fluctuations in relation to the menstrual cycle and use of $\mathrm{CHC}$, earlier studies have both smaller $(54,87)$ and larger $(57)$ sample sizes.

\section{Estrogenic or progestogenic effects?}

It is a weakness of the studies that the $\mathrm{CHC}$ users were using several different $\mathrm{CHCs}$. Eight of the $12 \mathrm{MS}$ patients using $\mathrm{CHC}$ in paper IV had a monophasic regimen with $30 \mu \mathrm{g}$ EE daily, one woman was on a monophasic regimen with $20 \mu \mathrm{g} E$ daily, one woman was on a triphasic regimen with $35 \mu \mathrm{g}$ EE daily, one women used a vaginal ring, and one woman used a transdermal patch. Six different progestogens were used in combination with EE. Given these differences we cannot conclude if there are differences between different $\mathrm{CHC}$ 
regarding the outcomes studied. This also raises the question whether the differences shown between the different sex steroid phases in the studies reflect the effects of estrogens, progestogens or both. Since $\mathrm{CHC}$ is a combination of an estrogen and a progestogen it is only possible to say that $\mathrm{CHCs}$ probably have the effects shown in the studies. Previous studies have shown that administration of E2 before induction of EAE protects against development of EAE (37-40) and that EE can even reduce disease severity after onset. $(43,44)$ There are few studies of the effects of progesterone $(49,50)$ and synthetic progestogens are not studied specifically. In the studies of the effects of E3 on MS, possible progesterone effects are possible. $(80,81)$ Taken together, we suggest that estrogens are probably involved in the effects of $\mathrm{CHC}$ and the menstrual cycle shown in the present studies and that progestogenic effects cannot be ruled out.

\section{Statistics}

In papers I and II the women scored their symptoms daily in the diaries using a set ordinal scale. These data were then transformed into mean values of periods of days repeated three times. Since the data were not normally distributed we used Wilcoxon's signed rank test to analyze whether the mean values differed significantly between the different phases. The results are presented as mean values for specified phases of the cycle over three cycles and the $\mathrm{p}$ value of the Wilcoxon's signed rank test (tables 7 and 8). It may be discussed whether it is statistically correct to count the mean of values from an ordinal scale and then use a nonparametric method to test the hypothesis. However, after several discussions with statisticians we found that this was the method that in the best way would describe the results from the present studies (papers I and II). 


\section{CONCLUSIONS}

From the results of the four studies and as answers to the research questions, the following conclusions are drawn.

- Women with MS without hormonal contraception did not report differences in symptom experience between different phases of the menstrual cycle. (Paper I and II)

- Women with MS who use CHC reported more severe symptoms during the pill-free week, with low estrogens and low progestogens, than during intake of CHC. (Paper I and II)

- Use of $\mathrm{CHC}$ and childbirth before onset of MS were related to a higher age at onset of the disease. (Paper III)

- Expression of the B cell-associated chemokine CXCL13 was generally higher in high the estrogen/progestogen phase than in the low estrogen/progestogen phase and the expression of the transcription factors showed a general activation of peripheral blood T cells during high estrogen and progestogen phases. No differences were shown between women with MS and healthy women or between women using $\mathrm{CHC}$ and women without hormonal contraception (paper IV).

\section{CLINICAL IMPLICATIONS}

MS is a serious neurological disease that strikes people, and especially women, around 20-40 years of age. From a clinical, gynaecological point of view, this age range is an essential phase of a woman's life when she is often either pregnant, is breastfeeding or needs a reliable contraceptive method. The aim of these studies was to increase the understanding of how different states of high and low levels of sex steroids affect women with MS in order to hopefully give these women a better counseling in contraceptive matters. One indirect finding of these studies was that women with MS probably were prescribed $\mathrm{CHC}$ to a lesser 
extent than healthy women. A main conclusion of these and other studies is that there is probably no reason for a woman with MS to abstain from $\mathrm{CHC}$ as contraceptive method as long as she is not too seriously immobilized. It is also probably beneficial to women with MS to have a continuous high serum concentration of some type of estrogen. One way to achieve this could be the use of $\mathrm{CHC}$ with longer estrogen/progestogen periods and fewer pill-free intervals in continuous-use regimens.

\section{FUTURE RESEARCH PERSPECTIVES}

It is difficult to design a study on human subjects in which the difference between specific estrogenic and progestogenic effects may be separately investigated since this would require surgical or medical castration followed by administration of the sex steroid studied. Hence, regarding the effects of sex steroids on MS, further studies of $\mathrm{CHC}$ will be easier to carry out. Based on the conclusions of the present and previous studies future research of women with MS should investigate the effects of longer periods of continuous $\mathrm{CHC}$ use on outcomes as MRI lesions, disease activity related cytokines and chemokines in CSF and peripheral blood and the women's experiences of their symptoms. Baseline measurements should be done before start of $\mathrm{CHC}$ use, after three continuous months of use and after a one month washout period. Even longer periods of continuous $\mathrm{CHC}$ use should be tested regarding annual relapse rate and long-term disease course measurements such as EDSS evolution and time to conversion into SPMS. Ideally, these kinds of studies should be carried out with all participating women using the same $\mathrm{CHC}$ and without immunomodulatory medication or at least using the same doses and regimens of immunomodulatory treatment. Regarding the effects of $\mathrm{CHC}$ on the incidence of MS, future cohort- or case-control studies should use a strict definition of type of hormonal contraception. 


\section{POPULÄRVETENSKAPLIG SAMMANFATTNING}

Multipel skleros (MS) är en potentiellt allvarlig autoimmun neurologisk sjukdom som oftast debuterar mellan 20 och 40 års ålder och förekomsten av MS är två till tre gånger högre bland kvinnor än bland män. Könshormoner, särskilt östrogener, har i djurförsök visat sig kunna påverka immunologiska sjukdomsprocesser-som liknar de som förekommer vid MS. Det finns också tidigare studier som visar att radiologiska och kliniska tecken på MS möjligen kan påverkas av könshormoner. Menscykeln och användning kombinerade (östrogeninnehållande) p-piller innebär cykliska variationer av blodets innehåll av könshormoner, vilket eventuellt kan påverka MS. För kvinnor mellan 20 och 40 år är det viktigt med en tillförlitlig preventivmedelsmetod, samtidigt som de befinner sig i den ålder då MS-incidensen är som högst. Effekterna av kombinerade p-piller på MS har dock inte studerats i särskilt stor utsträckning. Syftet med denna avhandling har varit att undersöka hur varierande könshormonnivåer under menstruationscykeln och användning av kombinerade $\mathrm{p}$-piller påverkar MS.

Delstudie I visade, i motsats till tidigare retrospektiva studier, att 16 kvinnor med naturlig menscykel i en prospektiv studie, upplevde ett av tretton MS-symtom svagare under en fas av menstruationscykeln där könshormonnivåerna är låga. Sju kvinnor som använde kombinerade $\mathrm{p}$-piller upplevde däremot tre av symtomen betydligt starkare under den tablettfria fasen då könshormonnivåerna är låga.

I delstudie II medverkade kvinnor med MS, som använde kombinerade p-piller. Dessa upplevde fyra av tio MS-symtom starkare under den tablettfria veckan. Kvinnor med MS som inte använde något hormonellt preventivmedel rapporterade inga skillnader $\mathrm{i}$ symtomupplevelse mellan olika faser av menscykeln.

I delstudie III besvarade 770 kvinnor med MS en enkät om bland annat p-pilleranvändning och graviditeter under livet. Resultaten visade att de kvinnor som hade använt kombinerade p-piller innan de fick MS hade insjuknat vid 26 års ålder i genomsnitt, medan de kvinnor som inte hade använt kombinerade p-piller insjuknande i MS vid 19 års ålder i genomsnitt. Ju längre tid kvinnorna hade använt kombinerade p-piller desto äldre var de vid insjuknandet i MS. 
I delstudie IV undersöktes hur blodkoncentrationer av cytokiner, kemokiner och transkriptionsfaktorer varierade mellan olika faser av menscykeln och p-pillercykeln hos kvinnor med MS och friska kvinnor. Det visade sig att i faser med höga könshormonnivåer var blodkoncentrationer av transkriptionsfaktorer för T-hjälparceller generellt hög liksom koncentrationen av det B-cells associerade kemokinet CXCL13.

Den kliniska slutsatsen av dessa och tidigare studier är att det troligen inte finns någon anledning för en kvinna med MS att inte använda kombinerade p-piller som preventivmedelsmetod bara för att hon har MS. Det är troligen också fördelaktigt för kvinnor med MS att använda regimer med glesare tablettuppehåll än var fjärde vecka. Framtida studier bör undersöka effekterna av sådana regimer på resultat som skovfrekvens, magnetkamerafynd, immunologisk sjukdomsaktivitet och symtomupplevelse. 


\section{AKNOWLEDGEMENTS}

My supervisor, Jan Brynhildsen, who has guided me during all these years that I have been working on this thesis. Although we've had the geography against us we finally succeeded. There have been a lot of ups and downs along the way and more than once I have been ready to give up. Every time, and even when I have failed, you have pushed me back on track. I would never have been able to finish this without you. Thank you!

Mats Hammar, my co-supervisor. In 1999, you were the first person who told me that I was to become a gynaecologist before I even knew it myself and you gave me the opportunity to work at your department. You always find alternative ways of doing things when the original plan doesn't work out. It has also been great to learn some of your skills in scientific writing.

Jan Ernerudh, my coach in immunology. You believed in our cross-over project and really made me feel welcome at AIR. With your guidance I believe that I have actually understood some things about immunology.

Anne-Marie Landtblom. You took part in the original plans for these studies, in the recruitment of study persons and in the design of the symptom diaries. During these years you have also been deeply involved in our contacts with the Swedish MS register. For these efforts I thank you very much.

Tomas Olsson. Due to your positive attitude to our ideas we were able to recruit patients at your department in Stockholm. If that hadn't happened we would still be searching for women to include and this book would still be a dream.

Therese Pollack and Susanne Sundqvist. Thank you for your help in recruiting patients and your positive and helpful attitude.

Gunn Johansson. I guess I have e-mailed and called you more than hundred times during these years to ask for your help. Every time you have managed to solve my problems and every time you have done it with a smile. You have helped me with the Swedish MS register contacts, you have helped me in recruiting patients and you have even visited patients at home on weekends to take blood samples. Thank you. 
Malena Söderström. Thank you for your help in recruiting patients in Sundsvall at the beginning of these studies.

Lotta Lindh-Åstrand. You have been involved in the studies from the beginning and have helped in many ways, both practical and theoretical. Thank you.

Daniel Eklund, important co-author of paper IV. You performed the PCR analyses, took part in the discussions regarding how to interpret the data and made the nice figures of the manuscript. It has been a real pleasure to work with you and I thank you especially for taking your time to answer my sometimes simple questions regarding molecular biology.

Petra Cassel and Agnes Hallin. Thank you for your excellent lab work!

Måns Edström. Thank you for your efforts in trying to make me understand PCR procedures and thank you for letting me use your figure. Congratulations to you and your newly wed wife!

Mohsen Khademi. You managed the logistics for the transport of the blood samples from Stockholm to Linköping and you kindly gave me your permission to use one of your figures in this book. Thank you.

Ann Johannesson and all staff of the gynecological outpatient ward at the university hospital, Linköping. Thank you for your help and positive attitude.

Lotta Dahle. Thank you for important reviewing of the studies along the way as well as help in recruiting patients together with Irene Håkansson.

Sofia Arenfors. Thank you for your help with data collection.

Oluf Andersen, Leszek Stawiarz and Jenny Link at the Swedish MS register. Thank you for your help during these studies.

Erling Englund and Mats Fredriksson. Thank you for your advices in statistics.

Preben Kjölhede, Göran Berg, Gabriella Falk, Eric Hildebrand and Anna-Clara Spetz. Thank you for reviewing the papers and the dissertation.

Larry Lundgren. Thank you for your review of the English language in this dissertation. 
Maria Rundberg and Ingela Olsson. Thank you for every train ticket you've helped me book and your kind assistance in various other matters.

Lars Berglund and Kicki Rapp, former heads of my clinical department in Sundsvall. Thank you for giving me the possibility to do this.

Kenneth Challis. Thank you for giving the time for these studies while you were the head of our department but foremost thanks for being a good friend and a great tennis opponent.

Marju Dahmoun, present head of my clinical department. You gave me the opportunity to finish these studies although you would rather have had me working the nights at the hospital. Thank you for that.

Marie Bolin. Thanks for being at the hospital all the time so that I could finish these studies. I also thank you for sharing my interest in labor and delivery and for your willingness to discuss that or any other matter that's important in life at almost any time.

My other two consultant colleagues of the obsterical team, Jesper Agrell and Sahruh Turkmen. I thank you for covering for me during this last year when my appearance at the hospital has been sparse.

All colleagues at the department of obstetrics and gynaecology at Sundsvall hospital. Thank you for letting me do this. Thank you for the positive atmosphere in our group, for discussions and laughter during the morning coffee break and for support during hard times.

Pär Persson. Without you I would probably not have become a gynaecologist. I have learned so much from you including gynecological surgery, wine, food and the usefulness of a Swiss army knife. You are a true friend.

Eva and Anders Kempe, my parents in law. Thank you for help with our children during times when I have been away to do these studies. I also thank you for countless days and nights of laughter, discussions, skiing, bathing, eating, drinking and all other things we do together. I couldn't have better parents in law.

Anna and Erik Kempe. Your decision to move to Sundsvall was an excellent one. Your help with our children during the last two years has been of great importance for the finishing of these studies. You are also good running partners and great friends. Thank you. 
My brothers and sisters and their partners Erik, Stina, Kajsa, Rasmus, Eva, Mattias and Axel. It's a great gift to have a big family. You all have your different ways of seeing things and we always have intense and interesting discussions when we meet. I love you all.

My father, Rolf Holmqvist. Since I was a child you have always supported me in studying. You have also taught me to question everything. Sometimes it's easier to just accept the so called facts but a true scientist, like you, is always skeptical. We often think differently about things but you have also showed me that having different opinions is not the same as not being friends. I also thank you for you guidance in statistics during these studies.

Bodil Davidsson-Holmqvist, my mother. Thank you for everything you've done for me during the years. Thank you for travelling all the way to Sundsvall to take care of our children when we've been away. Thank you for efforts during the building of the fantastic house in Duved. Thank you for always being there for me.

Johan, my son. I believe your brain works hundred times faster than the average brain. Ever since you were born you have come up with new ideas that you want to realize right away. We often argue because things doesn't happen as fast as you hope or not in the exact way you want them to happen. Your creativity is endless. You are a fantastic person and I love you.

Simon, my son. You are an amazing person in the way you care for people. You are a truly empathic person and that's a great gift. You become friends with everyone you meet and you make no difference based on superficial things. I look up to you and I try to learn from you. I love you.

Ebba, my daughter. Every day I get overwhelmed by your smartness and your fantastic memory. I love talking to you and your view of the world is amazing. I hope that your open mind opens up mine a bit too. Love you.

Sara, my love, my life, my world. For twenty years you have been the sunshine of my life and I have loved you every day. You have made large efforts to make it possible for me to finish these studies and I can't thank you enough. You are a bright journalist, a fantastic mother, an inspiring skiing partner, a reliable diving buddy, the most beautiful woman I have ever met, and my best friend. Je t'aime. 


\section{REFERENCES}

1. Noseworthy JH, Lucchinetti C, Rodriguez M, Weinshenker BG. Multiple Sclerosis. New England Journal of Medicine. 2000;343(13):938-52.

2. Compston A, Coles A. Multiple sclerosis. Lancet. 2008;372(9648):1502-17.

3. Nylander A, Hafler DA. Multiple sclerosis. The Journal of clinical investigation. 2012;122(4):1180-8.

4. Alonso A, Hernan MA. Temporal trends in the incidence of multiple sclerosis: a systematic review. Neurology. 2008;71(2):129-35.

5. Ahlgren C, Odén A, Lycke J. High nationwide prevalence of multiple sclerosis in Sweden. Multiple Sclerosis Journal. 2011;17(8):901-8.

6. Bostrom I, Stawiarz L, Landtblom AM. Sex ratio of multiple sclerosis in the National Swedish MS Register (SMSreg). Mult Scler. 2013;19(1):46-52.

7. Orton SM, Herrera BM, Yee IM, Valdar W, Ramagopalan SV, Sadovnick AD, et al. Sex ratio of multiple sclerosis in Canada: a longitudinal study. Lancet neurology. 2006;5(11):932-6.

8. Willer CJ, Dyment DA, Risch NJ, Sadovnick AD, Ebers GC. Twin concordance and sibling recurrence rates in multiple sclerosis. Proc Natl Acad Sci U S A. 2003;100(22):12877-82.

9. Schmidt $H$, Williamson $D$, Ashley-Koch A. HLA-DR15 haplotype and multiple sclerosis: a HuGE review. Am J Epidemiol. 2007;165(10):1097-109.

10. Qiu W, Pham K, James I, Nolan D, Castley A, Christiansen FT, et al. The influence of non-HLA gene polymorphisms and interactions on disease risk in a Western Australian multiple sclerosis cohort. Journal of Neuroimmunology. 2013;261(1-2):92-7.

11. Duquette $\mathrm{P}$, Girard M. Hormonal factors in susceptibility to multiple sclerosis. Current opinion in neurology and neurosurgery. 1993;6(2):195-201.

12. Pozzilli C, Tomassini V, Marinelli F, Paolillo A, Gasperini C, Bastianello S. 'Gender gap' in multiple sclerosis: magnetic resonance imaging evidence. European journal of neurology : the official journal of the European Federation of Neurological Societies. 2003;10(1):95-7.

13. Lucas RM, Ponsonby AL, Dear K, Valery PC, Pender MP, Taylor BV, et al. Sun exposure and vitamin D are independent risk factors for CNS demyelination. Neurology. 2011;76(6):540-8. 14. Munger KL, Levin LI, Hollis BW, Howard NS, Ascherio A. SErum 25-hydroxyvitamin d levels and risk of multiple sclerosis. JAMA. 2006;296(23):2832-8.

15. Simpson S, Jr., Taylor B, Blizzard L, Ponsonby AL, Pittas F, Tremlett H, et al. Higher 25hydroxyvitamin $\mathrm{D}$ is associated with lower relapse risk in multiple sclerosis. Annals of neurology. 2010;68(2):193-203. 
16. Burton JM, Kimball S, Vieth R, Bar-Or A, Dosch HM, Cheung R, et al. A phase I/II doseescalation trial of vitamin D3 and calcium in multiple sclerosis. Neurology. 2010;74(23):1852-9. 17. Hernan MA, Zhang SM, Lipworth L, Olek MJ, Ascherio A. Multiple sclerosis and age at infection with common viruses. Epidemiology. 2001;12(3):301-6.

18. Ascherio A, Munger KL. Environmental risk factors for multiple sclerosis. Part I: the role of infection. Annals of neurology. 2007;61(4):288-99.

19. Hedstrom AK, Baarnhielm M, Olsson T, Alfredsson L. Tobacco smoking, but not Swedish snuff use, increases the risk of multiple sclerosis. Neurology. 2009;73(9):696-701.

20. Carlens C, Hergens MP, Grunewald J, Ekbom A, Eklund A, Hoglund CO, et al. Smoking, use of moist snuff, and risk of chronic inflammatory diseases. Am J Respir Crit Care Med. 2010;181(11):1217-22.

21. Ercolini AM, Miller SD. Mechanisms of immunopathology in murine models of central nervous system demyelinating disease. Journal of immunology. 2006;176(6):3293-8.

22. Abbas AK, Lichtman AH, Pillai S. Cellular and molecular immunology. 7. ed. Philadelphia: Elsevier/Saunders; 2012. x, 545 s. p.

23. Frohman EM, Racke MK, Raine CS. Multiple Sclerosis - The Plaque and Its Pathogenesis. New England Journal of Medicine. 2006;354(9):942-55.

24. Wekerle H, Berer K, Krishnamoorthy G. Remote control-triggering of brain autoimmune disease in the gut. Current opinion in immunology. 2013;25(6):683-9.

25. Fujinami RS, von Herrath MG, Christen U, Whitton JL. Molecular mimicry, bystander activation, or viral persistence: infections and autoimmune disease. Clinical microbiology reviews. 2006;19(1):80-94.

26. Vanderlugt $\mathrm{CL}$, Miller SD. Epitope spreading in immune-mediated diseases: implications for immunotherapy. Nature reviews Immunology. 2002;2(2):85-95.

27. Comabella M, Khoury SJ. Immunopathogenesis of multiple sclerosis. Clinical immunology. 2012;142(1):2-8.

28. Ellwardt E, Zipp F. Molecular mechanisms linking neuroinflammation and neurodegeneration in MS. Experimental neurology. 2014.

29. Polman CH, Reingold SC, Banwell B, Clanet M, Cohen JA, Filippi M, et al. Diagnostic criteria for multiple sclerosis: 2010 revisions to the McDonald criteria. Annals of neurology. 2011;69(2):292-302.

30. Zivadinov R. Advanced magnetic resonance imaging metrics: implications for multiple sclerosis clinical trials. Methods Find Exp Clin Pharmacol. 2009;31(1):29-40. 
MRI and newly emerging MRI techniques in monitoring different aspects of treatment outcome. J Neurol. 2008;255 Suppl 1:61-74.

32. Dahlman-Wright K, Cavailles V, Fuqua SA, Jordan VC, Katzenellenbogen JA, Korach KS, et al. International Union of Pharmacology. LXIV. Estrogen receptors. Pharmacological reviews. 2006;58(4):773-81.

33. Maggiolini M, Picard D. The unfolding stories of GPR30, a new membrane-bound estrogen receptor. The Journal of endocrinology. 2010;204(2):105-14.

34. Damber MG, Sandstrom B, von Schoultz B, Stigbrand T. A new and sensitive method for quantifying and comparing the biological potency of varius estrogens in man. Acta obstetricia et gynecologica Scandinavica. 1979;58(6):527-30.

35. Stanczyk FZ, Archer DF, Bhavnani BR. Ethinyl estradiol and $17 \beta$-estradiol in combined oral contraceptives: pharmacokinetics, pharmacodynamics and risk assessment. Contraception. 2013;87(6):706-27.

36. Speroff L, Glass RH, Kase NG. Clinical gynecologic endocrinology and infertility. 6th ed ed. Philadelphia: Lippincott Williams \& Wilkins; 1999. x, 1200 p. p.

37. Ito A, Bebo BF, Matejuk A, Zamora A, Silverman M, Fyfe-Johnson A, et al. Estrogen Treatment Down-Regulates TNF- $\alpha$ Production and Reduces the Severity of Experimental Autoimmune Encephalomyelitis in Cytokine Knockout Mice. The Journal of Immunology. 2001;167(1):542-52.

38. Polanczyk M, Zamora A, Subramanian S, Matejuk A, Hess DL, Blankenhorn EP, et al. The Protective Effect of $17 \beta$-Estradiol on Experimental Autoimmune Encephalomyelitis Is Mediated through Estrogen Receptor- $\alpha$. The American Journal of Pathology. 2003;163(4):1599-605.

39. Wang C, Dehghani B, Li Y, Kaler LJ, Proctor T, Vandenbark AA, et al. Membrane estrogen receptor regulates experimental autoimmune encephalomyelitis through up-regulation of programmed death 1. Journal of immunology. 2009;182(5):3294-303.

40. Subramanian S, Yates $M$, Vandenbark AA, Offner H. Oestrogen-mediated protection of experimental autoimmune encephalomyelitis in the absence of Foxp3+ regulatory $T$ cells implicates compensatory pathways including regulatory B cells. Immunology. 2011;132(3):340-7.

41. Elloso MM, Phiel K, Henderson RA, Harris HA, Adelman SJ. Suppression of experimental autoimmune encephalomyelitis using estrogen receptor-selective ligands. The Journal of endocrinology. 2005;185(2):243-52.

42. Morales LB, Loo KK, Liu HB, Peterson C, Tiwari-Woodruff S, Voskuhl RR. Treatment with an estrogen receptor alpha ligand is neuroprotective in experimental autoimmune 
encephalomyelitis. The Journal of neuroscience : the official journal of the Society for Neuroscience. 2006;26(25):6823-33.

43. Subramanian S, Matejuk A, Zamora A, Vandenbark AA, Offner H. Oral Feeding with Ethinyl Estradiol Suppresses and Treats Experimental Autoimmune Encephalomyelitis in SJL Mice and Inhibits the Recruitment of Inflammatory Cells into the Central Nervous System. The Journal of Immunology. 2003;170(3):1548-55.

44. Yates MA, Li Y, Chlebeck PJ, Offner H. GPR30, but not estrogen receptor-alpha, is crucial in the treatment of experimental autoimmune encephalomyelitis by oral ethinyl estradiol. BMC immunology. 2010;11:20.

45. Ito A, Buenafe AC, Matejuk A, Zamora A, Silverman M, Dwyer J, et al. Estrogen inhibits systemic T cell expression of TNF-alpha and recruitment of TNF-alpha(+) T cells and macrophages into the CNS of mice developing experimental encephalomyelitis. Clinical immunology. 2002;102(3):27582.

46. Polanczyk MJ, Hopke C, Vandenbark AA, Offner H. Estrogen-mediated immunomodulation involves reduced activation of effector T cells, potentiation of Treg cells, and enhanced expression of the PD-1 costimulatory pathway. J Neurosci Res. 2006;84(2):370-8. 47. Bodhankar S, Vandenbark AA, Offner H. Oestrogen treatment of experimental autoimmune encephalomyelitis requires $17 \beta$-oestradiol-receptor-positive B cells that up-regulate PD1 on CD4+ Foxp3+ regulatory T cells. Immunology. 2012;137(4):282-93.

48. Bodhankar S, Wang C, Vandenbark AA, Offner H. Estrogen-induced protection against experimental autoimmune encephalomyelitis is abrogated in the absence of B cells. European journal of immunology. 2011;41(4):1165-75.

49. Giatti S, Caruso D, Boraso M, Abbiati F, Ballarini E, Calabrese D, et al. Neuroprotective effects of progesterone in chronic experimental autoimmune encephalomyelitis. Journal of neuroendocrinology. 2012;24(6):851-61.

50. Yates MA, Li Y, Chlebeck P, Proctor T, Vandenbark AA, Offner H. Progesterone treatment reduces disease severity and increases IL-10 in experimental autoimmune encephalomyelitis. Journal of Neuroimmunology. 2010;220(1-2):136-9.

51. Smith R, Studd JW. A pilot study of the effect upon multiple sclerosis of the menopause, hormone replacement therapy and the menstrual cycle. Journal of the Royal Society of Medicine. 1992;85(10):612-3.

52. Zorgdrager A, De Keyser J. Menstrually related worsening of symptoms in multiple sclerosis. Journal of the Neurological Sciences. 1997;149(1):95-7.

53. Zorgdrager A, De Keyser J. The Premenstrual Period and Exacerbations in Multiple Sclerosis. European neurology. 2002;48(4):204-6. 
54.

Faas M, Bouman A, Moesa H, Heineman MJ, de Leij L, Schuiling G. The immune response during the luteal phase of the ovarian cycle: a Th2-type response? Fertility and Sterility. 2000;74(5):1008-13.

55. Bansil S, Lee HJ, Jindal S, Holtz CR, Cook SD. Correlation between sex hormones and magnetic resonance imaging lesions in multiple sclerosis. Acta neurologica Scandinavica. 1999;99(2):91-4.

56. Pozzilli C, Falaschi P, Mainero C, Martocchia A, D'Urso R, Proietti A, et al. MRI in multiple sclerosis during the menstrual cycle: relationship with sex hormone patterns. Neurology. 1999;53(3):622-4.

57. Arruvito L, Sanz M, Banham AH, Fainboim L. Expansion of CD4+CD25+and FOXP3+ regulatory $T$ cells during the follicular phase of the menstrual cycle: implications for human reproduction. Journal of immunology. 2007;178(4):2572-8.

58.

Hernan MA, Hohol MJ, Olek MJ, Spiegelman D, Ascherio A. Oral contraceptives and the incidence of multiple sclerosis. Neurology. 2000;55(6):848-54.

59. Thorogood M, Hannaford PC. The influence of oral contraceptives on the risk of multiple sclerosis. British journal of obstetrics and gynaecology. 1998;105(12):1296-9.

60. Gava G, Bartolomei I, Costantino A, Berra M, Venturoli S, Salvi F, et al. Long-term influence of combined oral contraceptive use on the clinical course of relapsing-remitting multiple sclerosis. Fertility and Sterility. 2014.

61. Alonso A, Jick SS, Olek MJ, Ascherio A, Jick H, Hernan MA. Recent use of oral contraceptives and the risk of multiple sclerosis. Arch Neurol. 2005;62(9):1362-5.

62. Sena A, Couderc R, Vasconcelos JC, Ferret-Sena V, Pedrosa R. Oral contraceptive use and clinical outcomes in patients with multiple sclerosis. J Neurol Sci. 2012;317(1-2):47-51.

63. D'hooghe MB, Haentjens P, Nagels G, D'Hooghe T, Keyser J. Menarche, oral contraceptives, pregnancy and progression of disability in relapsing onset and progressive onset multiple sclerosis. J Neurol. 2012;259(5):855-61.

64. Bernardi S, Grasso MG, Bertollini R, Orzi F, Fieschi C. The influence of pregnancy on relapses in multiple sclerosis: a cohort study. Acta neurologica Scandinavica. 1991;84(5):403-6. 65. Damek DM, Shuster EA. Pregnancy and multiple sclerosis. Mayo Clin Proc. 1997;72(10):977-89 .

66. Houtchens MK. Pregnancy and multiple sclerosis. Semin Neurol. 2007;27(5):434-41.

67. Hutchinson M. Pregnancy in multiple sclerosis. J Neurol Neurosurg Psychiatry. 1993;56(10):1043-5. 
68. Vukusic S, Hutchinson M, Hours M, Moreau T, Cortinovis-Tourniaire P, Adeleine P, et al. Pregnancy and multiple sclerosis (the PRIMS study): clinical predictors of post-partum relapse. Brain. 2004;127(6):1353-60.

69. Confavreux C, Hutchinson M, Hours MM, Cortinovis-Tourniaire P, Moreau T. Rate of Pregnancy-Related Relapse in Multiple Sclerosis. New England Journal of Medicine. 1998;339(5):28591.

70. Langer-Gould A, Huang SM, Gupta R, Leimpeter AD, Greenwood E, Albers KB, et al. Exclusive breastfeeding and the risk of postpartum relapses in women with multiple sclerosis. Arch Neurol. 2009;66(8):958-63.

71. Ponsonby AL, Lucas RM, van der Mei IA, Dear K, Valery PC, Pender MP, et al. Offspring number, pregnancy, and risk of a first clinical demyelinating event: the AusImmune Study. Neurology. 2012;78(12):867-74.

72. Runmarker B, Andersen O. Pregnancy is associated with a lower risk of onset and a better prognosis in multiple sclerosis. Brain. 1995;118 ( Pt 1):253-61.

73. D'hooghe MB, Nagels G, Uitdehaag BMJ. Long-term effects of childbirth in MS. Journal of Neurology, Neurosurgery \& Psychiatry. 2010;81(1):38-41.

74. Elenkov IJ, Wilder RL, Bakalov VK, Link AA, Dimitrov MA, Fisher S, et al. IL-12, TNFalpha, and hormonal changes during late pregnancy and early postpartum: implications for autoimmune disease activity during these times. J Clin Endocrinol Metab. 2001;86(10):4933-8. 75. Sanchez-Ramon S, Navarro AJ, Aristimuno C, Rodriguez-Mahou M, Bellon JM, Fernandez-Cruz E, et al. Pregnancy-induced expansion of regulatory T-lymphocytes may mediate protection to multiple sclerosis activity. Immunol Lett. 2005;96(2):195-201.

76. Saraste M, Vaisanen S, Alanen A, Airas L. Clinical and immunologic evaluation of women with multiple sclerosis during and after pregnancy. Gend Med. 2007;4(1):45-55.

77. Formby B. Immunologic response in pregnancy. Its role in endocrine disorders of pregnancy and influence on the course of maternal autoimmune diseases. Endocrinol Metab Clin North Am. 1995;24(1):187-205.

78. Saito S, Nakashima A, Shima T, Ito M. REVIEW ARTICLE: Th1/Th2/Th17 and Regulatory T-Cell Paradigm in Pregnancy. American Journal of Reproductive Immunology. 2010;63(6):601-10. 79. Holmqvist P, Wallberg M, Hammar M, Landtblom AM, Brynhildsen J. Symptoms of multiple sclerosis in women in relation to sex steroid exposure. Maturitas. 2006;54(2):149-53. 80. Sicotte NL, Liva SM, Klutch R, Pfeiffer P, Bouvier S, Odesa S, et al. Treatment of multiple sclerosis with the pregnancy hormone estriol. Annals of neurology. 2002;52(4):421-8. 
81. Soldan SS, Retuerto AIA, Sicotte NL, Voskuhl RR. Immune Modulation in Multiple Sclerosis Patients Treated with the Pregnancy Hormone Estriol. The Journal of Immunology. 2003;171(11):6267-74.

82. Kipp M, Amor S, Krauth R, Beyer C. Multiple sclerosis: Neuroprotective alliance of estrogen-progesterone and gender. Frontiers in Neuroendocrinology. 2012;33(1):1-16.

83. Sundstrom I, Nyberg S, Bixo M, Hammarback S, Backstrom T. Treatment of premenstrual syndrome with gonadotropin-releasing hormone agonist in a low dose regimen. Acta obstetricia et gynecologica Scandinavica. 1999;78(10):891-9.

84. Kurtzke JF. Rating neurologic impairment in multiple sclerosis: an expanded disability status scale (EDSS). Neurology. 1983;33(11):1444-52.

85. Edström M, Mellergård J, Mjösberg J, Jenmalm M, Vrethem M, Press R, et al.

Transcriptional characteristics of CD4+ T cells in multiple sclerosis: Relative lack of suppressive populations in blood. Multiple Sclerosis Journal. 2011;17(1):57-66.

86. Wingerchuk DM, Rodriguez M. Premenstrual multiple sclerosis pseudoexacerbations: Role of body temperature and prevention with aspirin. Archives of Neurology. 2006;63(7):1005-8. 87. Lee S, Kim J, Jang B, Hur S, Jung U, Kil K, et al. Fluctuation of Peripheral Blood T, B, and NK Cells during a Menstrual Cycle of Normal Healthy Women. The Journal of Immunology. 2010;185(1):756-62.

88. Lalor SJ, Segal BM. Lymphoid chemokines in the CNS. Journal of Neuroimmunology. 2010;224(1-2):56-61.

89. Bagaeva LV, Rao P, Powers JM, Segal BM. CXC Chemokine Ligand 13 Plays a Role in Experimental Autoimmune Encephalomyelitis. The Journal of Immunology. 2006;176(12):7676-85. 90. Sellebjerg F, Bornsen L, Khademi M, Krakauer M, Olsson T, Frederiksen JL, et al. Increased cerebrospinal fluid concentrations of the chemokine CXCL13 in active MS. Neurology. 2009;73(23):2003-10.

91. Khademi M, Dring AM, Gilthorpe JD, Wuolikainen A, Al Nimer F, Harris RA, et al. Intense inflammation and nerve damage in early multiple sclerosis subsides at older age: a reflection by cerebrospinal fluid biomarkers. PLoS One. 2013;8(5):e63172.

92. Rolle L, Memarzadeh Tehran M, Morell-Garcia A, Raeva Y, Schumacher A, Hartig R, et al. Cutting edge: IL-10-producing regulatory B cells in early human pregnancy. Am J Reprod Immunol. 2013;70(6):448-53.

93. Auerbach L, Hafner T, Huber JC, Panzer S. Influence of low-dose oral contraception on peripheral blood lymphocyte subsets at particular phases of the hormonal cycle. Fertility and Sterility. 2002;78(1):83-9. 
94. Putheti P, Morris M, Stawiarz L, Teleshova N, Kivisäkk P, Pashenkov M, et al. Multiple sclerosis: a study of chemokine receptors and regulatory T cells in relation to MRI variables. European Journal of Neurology. 2003;10(5):529-35.

95. Lindh I, Ellstrom AA, Blohm F, Milsom I. A longitudinal study of contraception and pregnancies in the same women followed for a quarter of a century. Human reproduction. 2010;25(6):1415-22.

96. Bartosik-Psujek H, Stelmasiak Z. The levels of chemokines CXCL8, CCL2 and CCL5 in multiple sclerosis patients are linked to the activity of the disease. European Journal of Neurology. $2005 ; 12(1): 49-54$.

97. Bartosik-Psujek H, Stelmasiak Z. Correlations between IL-4, IL-12 levels and CCL2, CCL5 levels in serum and cerebrospinal fluid of multiple sclerosis patients. J Neural Transm. 2005;112(6):797-803.

98. Franciotta D, Martino G, Zardini E, Furlan R, Bergamaschi R, Andreoni L, et al. Serum and CSF levels of MCP-1 and IP-10 in multiple sclerosis patients with acute and stable disease and undergoing immunomodulatory therapies. Journal of Neuroimmunology. 2001;115(1-2):192-8. 99. Potter L, Oakley D, de Leon-Wong E, Canamar R. Measuring compliance among oral contraceptive users. Family planning perspectives. 1996;28(4):154-8. 
Supplement 1

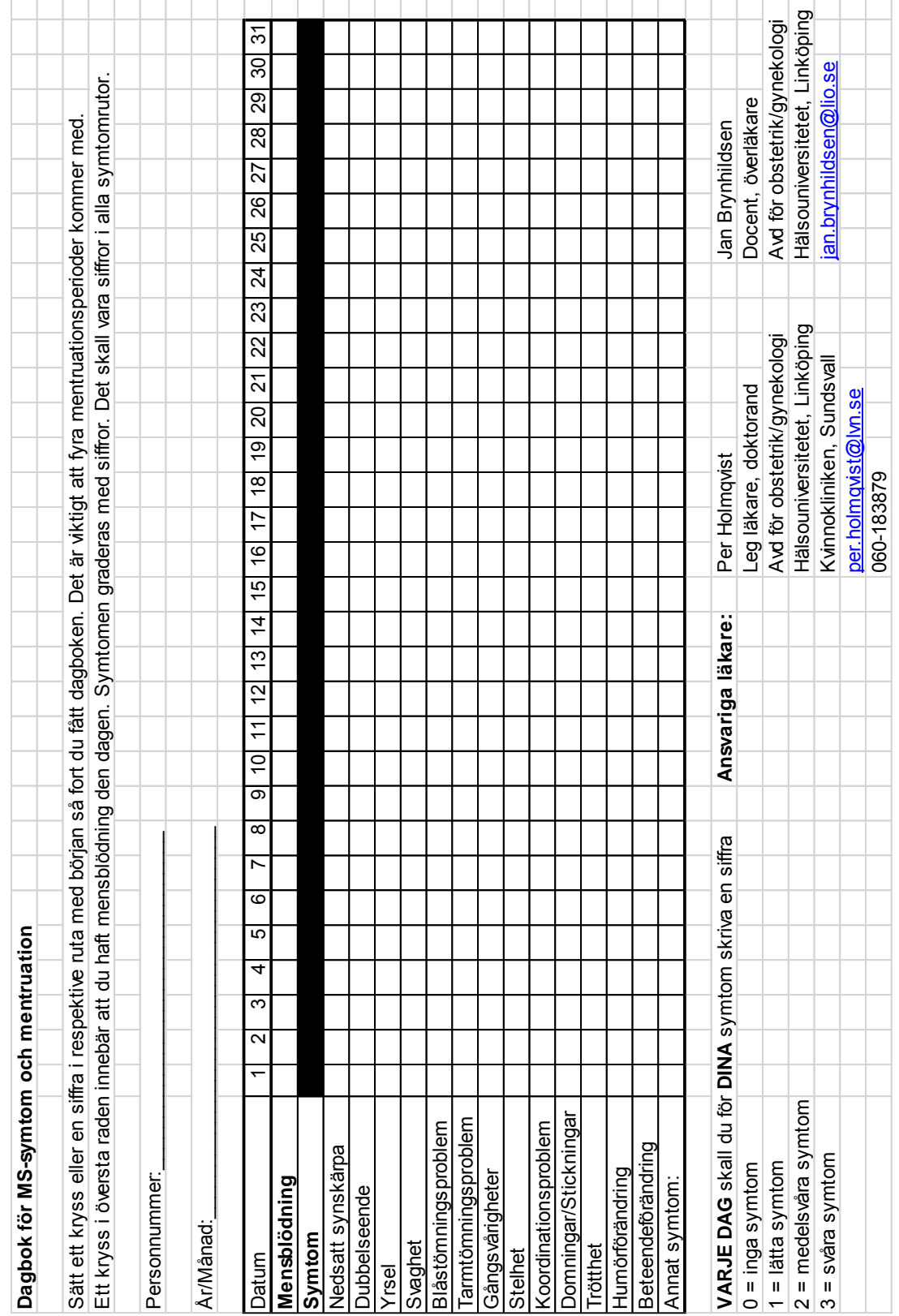




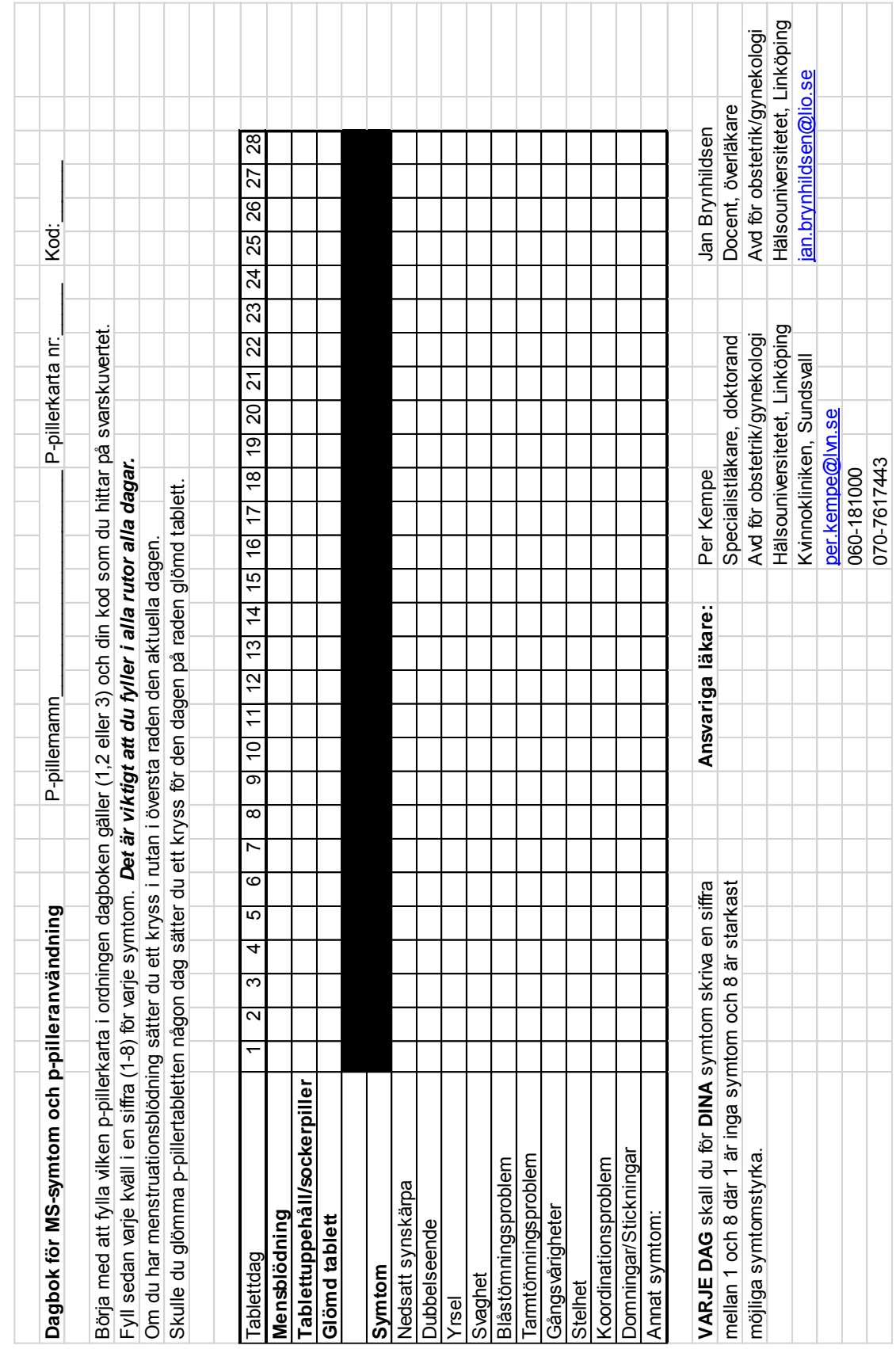




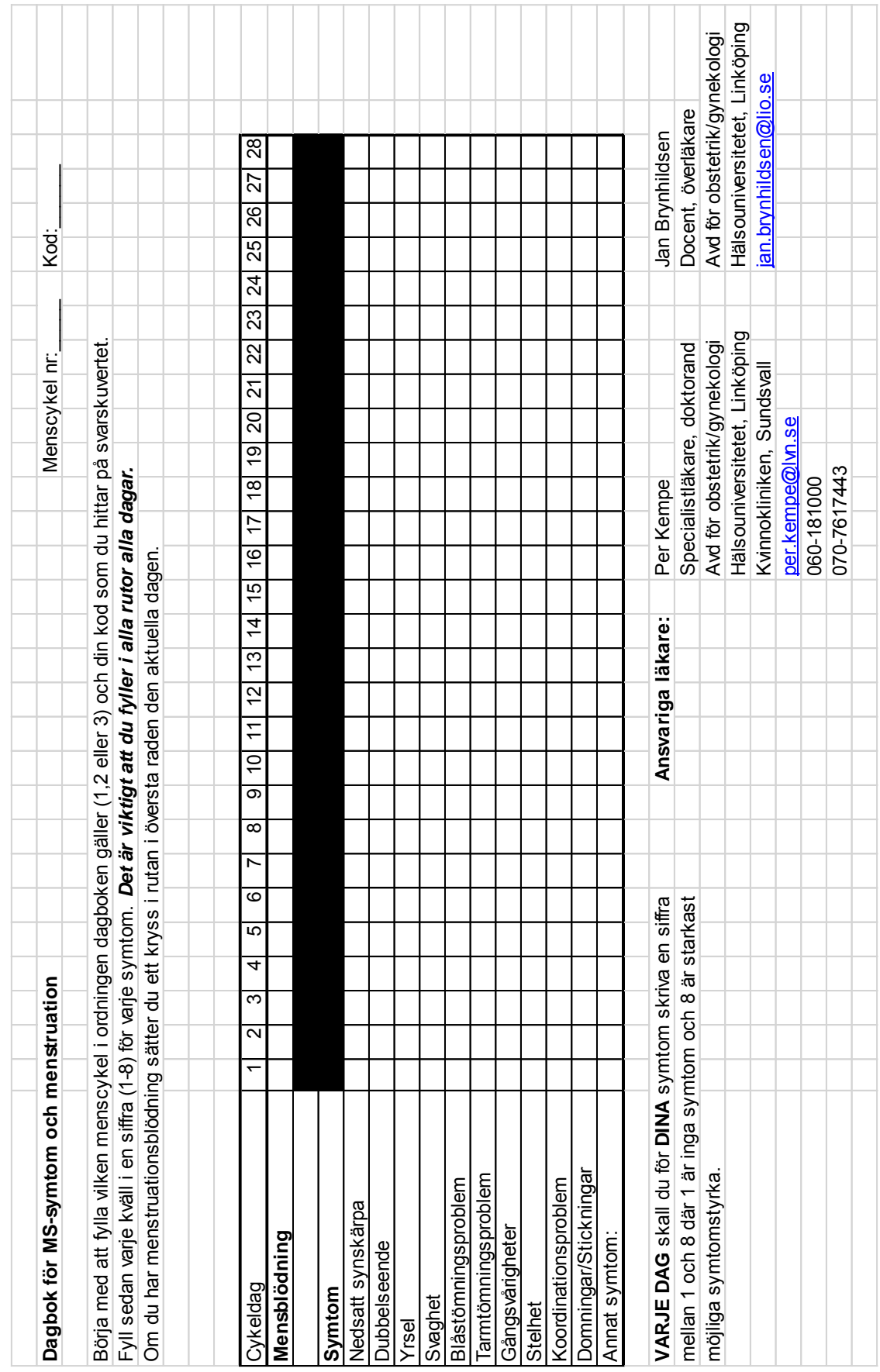




\section{Enkät kring MS, graviditet och p-pillerbruk}

Vi är mycket tacksamma om Du fyller i nedanstående frågor så noga du kan. Använd kulspetspenna och markera med ett tydligt kryss i rutan. Om Du ändrar Dig, fyll då i hela rutan med färg och sätt ett tydligt kryss i den ruta som är den rätta.

Notera att et är viktigt att du svarar på samtliga frågor. Om inget alternativ stämmer perfekt - svara då med det alternativ som passar bäst.

1. Hur gammal var du när du fick diagnosen MS?

år

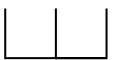

2. Hur gammal var du när du fick ditt första MS-symtom, även om diagnosen ställts vid ett senare tillfälle?

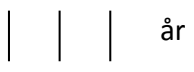

3. Hur länge har du haft MS?

År

4. Har du använt p-piller (ej minipiller), dvs den typ av p-piller man använder tre veckor och härefter har en veckas tablettuppehåll eller använder "sockerpiller" under en vecka?

Ja

Nej 
5. Under hur lång tid har du sammanlagt använt p-piller (ej minipiller), dvs den typ av p-piller man använder tre veckor och härefter har en veckas tablettuppehåll eller använder "sockerpiller" under en vecka?

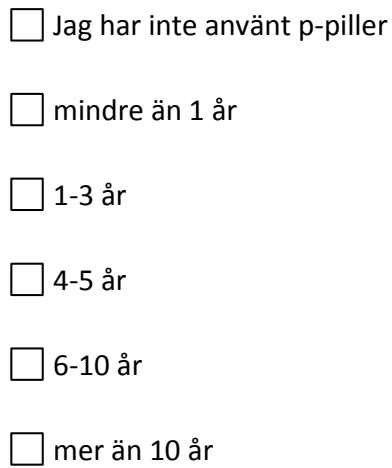

6. Hur gammal var du när du började med p-piller?

$\square$ Jag har inte använt p-piller

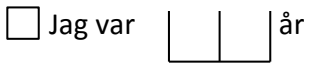

7. Hur många år har du använt p-piller innan du fick dina första MS-symtom?

$\square$ Jag har inte använt p-piller

$\square$ Jag har inte använt p-piller innan jag fick MS-symtom

$\square$ mindre än 1 år

1-3 år

4-5 år

6-10 år

mer än 10 år 
8. Hur många år har du använt p-piller efter du fick dina första MS-symtom?

$\square$ Jag har inte använt p-piller

$\square$ Jag har inte använt p-piller efter att jag fick MS-symtom

$\square$ mindre än 1 år

$\square 1-3$ år

$\square$ 4-5 år

6-10 år

mer än 10 år

9. Har du varit gravid?

$\square$ Ja

$\square$ Nej

10. Hur många gånger har du varit gravid? (inklusive missfall och aborter)

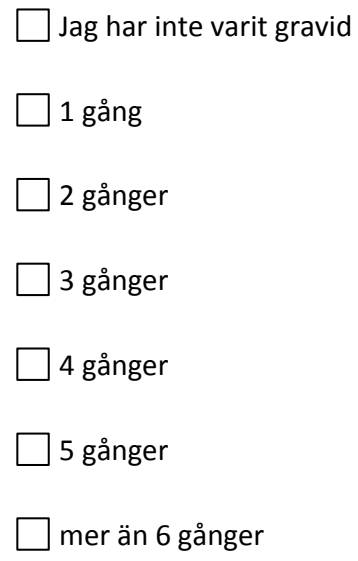


11. Hur många av dessa graviditeter inföll innan du fick dina första symtom på MS?

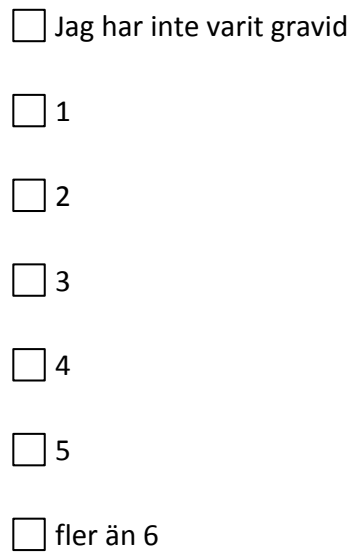

12. Hur många barn har du fött?

$\square$ Jag har inte varit gravid

$\square$ Jag har varit gravid men ej fött barn

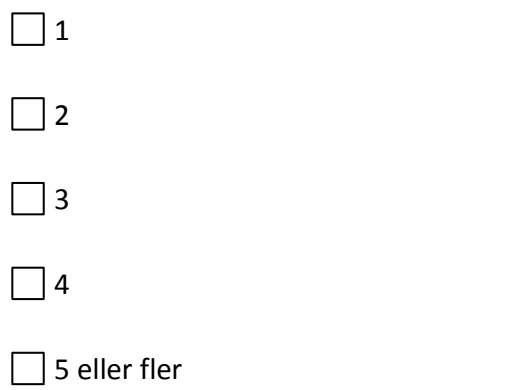


13. Hur många av dessa föddes innan du fick dina första symtom på MS?

$\square$ Jag har inte varit gravid

$\square$ Jag har varit gravid men ej fött barn

$\square$ Inget av mina barn föddes innan jag fick symtom på MS

$\square 1$

$\square 2$

3

4

5 eller fler

14. Har du under någon av dina graviditeter noterat någon förändring i MS-symtom?

$\square$ Jag har ej varit gravid

$\square$ Jag hade ej fått MS-symtom när jag var gravid

$\square$ Ja - färre eller mildare MS symtom

$\square$ Ja - fler eller värre MS symtom

Nej - jag har inte noterat någon skillnad i MS symtom när jag varit gravid 
15. Har du ammat?

$\square$ Ja

$\square$ Nej

16. Under hur lång tid har du sammanlagt ammat?

$\square$ Jag har inte varit gravid

$\square$ Jag har varit gravid men aldrig ammat

Mindre än 3 månader

4-6 månader

7-12 månader

13-18 månader

19-24 månader

mer än 2 år

17. Har du under någon av dina amningsperioder noterat någon förändring i MS symtom?

$\square$ Jag har ej ammat

$\square$ Jag hade ej fått MS-symtom när jag ammade

$\square$ Ja-färre eller mildare MS symtom

$\square$ Ja - fler eller värre MS symtom

$\square$ Nej - jag har inte noterat någon skillnad i MS symtom när jag ammat 
18. Röker du dagligen?

$\square$ Nej

Ja, mindre än 10 cigaretter per dag

Ja, 10 cigaretter per dag eller mer

19. Får du eller har du använt "bromsmedicin"?

Ja

Nej

20. Vilken eller vilka mediciner?

21. Under hur lång tid har du använt "bromsmedicin"

$\square$ Jag har inte använt bromsmedicin

mindre än 1 år

1-2 år

3-4 år

5 år eller längre 
22. Har du någon av följande sjukdomar?

$\square$ Hjärtsjukdom

$\square$ Högt blodtryck

Astma

$\square$ Benskörhet

Höga blodfetter

$\square$ Jag har ingen av ovanstående sjukdomar

23. Hur lång är du?

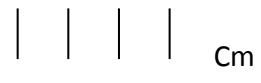

24. Hur mycket väger du? $\mathrm{Kg} \mid$

Tack för att du tagit dig tid att fylla i denna enkät. Kontrollera att du svarat på samtliga frågor. 



\section{Papers}

The articles associated with this thesis have been removed for copyright reasons. For more details about these see:

http://urn.kb.se/resolve?urn=urn:nbn:se:liu:diva-108888 